\title{
Marsilio Ficino on the Triad Being-Life-Intellect and the Demiurge: Renaissance Reappraisals of Late Ancient Philosophical and Theological Debates
}

\author{
Denis J.-J. Robichaud \\ University of Notre Dame
}

$\mathbf{1}$

The Platonic Triad Being-Life-Intellect and Theology in the Middle Ages

Neoplatonists often turn to the triad being-life-intellect to understand the nature of reality and demiurgy. The modern scholar often cited as the first to investigate the origins of this triad is E.R. Dodds, who devoted a couple of pages to the topic in his commentary on Proclus's Elements of Theology in $1933 .{ }^{1}$ As Dodds notes, the triad being-life-intellect is older than the Neoplatonists since it finds its origins in a passage from Plato's Sophist (248e) where the Eleatic Stranger proclaims:

But for heaven's sake, shall we let ourselves easily be persuaded that

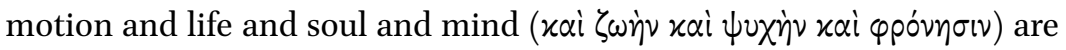
really not present to absolute being ( $\tau \hat{\omega} \pi \alpha \nu \tau \varepsilon \lambda \hat{\omega} \varsigma$ ŏ $\nu \tau \iota)$, that it neither lives nor thinks, but awful and holy, devoid of mind, is fixed and immovable

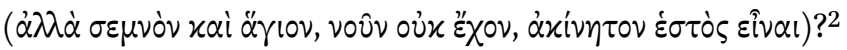

Plato here begins to interlock the terms into a triad to explain the nature of absolute or fully complete being as something that also lives and thinks. Plato's student Aristotle must have learned something from his teacher since we find

1 Proclus, Elements of Theology, esp. p. 220-221, 252-254. See also Beierwaltes 1979, p. 158-164, Gersh 1978, p. 45-57, and more recently d'Hoine 2017. Translations are mine unless I am quoting a translation in the bibliography.

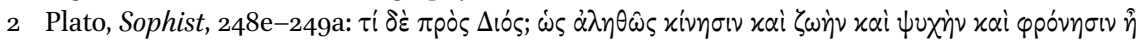

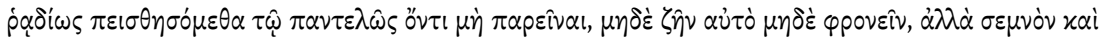

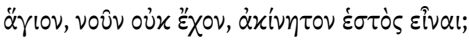


Aristotle employing the same terms of the triad in his famous discussion of the nature of God in Metaphysics $\Lambda$ (1072b), where, everyone surely remembers, Aristotle states that "life belongs to God," since God is a divine intellect that is

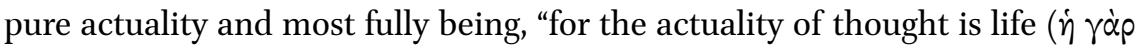

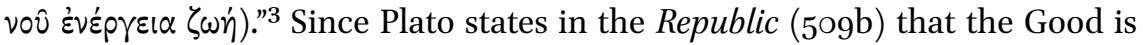
beyond being, and in the Sophist that being itself must also have thought and life, Neoplatonists pondered how reality derived being, life, and intellect from something that surpasses being (and therefore also life and intellect).

Moreover, in the Timaeus (39e) Plato also speaks of the Demiurge as fabricating by reproducing a pre-existing paradigm, that is by making living beings in the cosmos according to the same number that exist in the paradigmatic essential living being itself:

So this part of the work which was still undone he completed by molding it after the nature of the model. According, then, as intellect perceives forms existing in the absolute living creature, such and so many as exist therein did he deem that this world also should possess. ${ }^{4}$

Should one interpret this passage from the Timaeus as stating that the Demiurge's Intellect thinks of the paradigm as something outside of itself or not, and should one understand what it thinks as one or many? One strategy to answer these questions is to gloss Plato's explanation of demiurgy in the Timaeus with the help of Aristotle's theory that intellect is identical to its activity of thinking and its object of thought. The Demiurge would then be identical to the paradigms according to which he made the cosmos. Another strategy, however, is to keep the paradigm of the essential living being separate from the Demiurge. In both cases, the triad being-life-intellect becomes divine principles either, in the former case, as identical to the Demiurge's noetic activity or, in the latter case, as paradigms separate from and higher than the Demiurge. As we shall see, Iamblichus and Proclus's choice to adopt a version of the latter strategy had an impact on future philosophical and theological debates about the natures of the triad being-life-intellect and demiurgy.

It is now common knowledge that the Corpus Dionysiacum is heavily indebted to Proclus and the Athenian school of Neoplatonism, where the triad

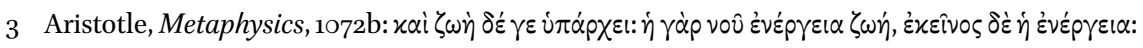

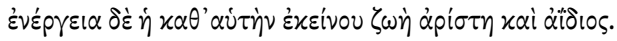

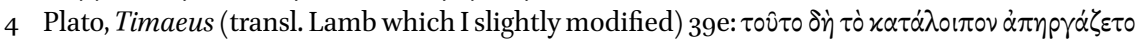

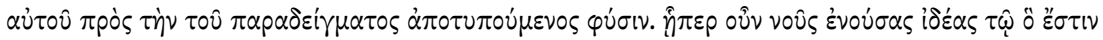

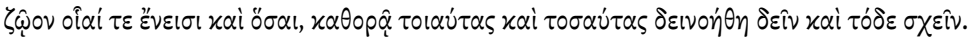


being-life-intellect became especially prevalent. Although the use of the triad being-life-intellect by Christian theologians dates to an earlier period than the Corpus Dionysiacum, it comes as no surprise that it is with Dionysius the Ps.Areopagite that one finds perhaps the most explicit Christian Neoplatonizing of the Godhead with this triad. The author of the De divinis nominibus employs the triad specifically as divine names for God, devoting sequential chapters of the work to explain how God can be said to be being, life, wisdom or intellect, while also saying that God is beyond being.

What I have to say is concerned with the benevolent providence made known to us, and my speech of praise is for the transcendentally good cause of all good things, for that being and life and wisdom, for that cause of existence and life and wisdom among those creatures with their own share in being, life, intelligence, expression, and perception. I do not think of the good as one thing, being as another, life and wisdom as yet another, and I do not claim that there are numerous causes and different Godheads, all differently ranked, superior and inferior, and all producing different effect. No. But I hold that there is one God for all these good processions and that he is the possessor of the divine names of which I speak and that the first name tells of the universal providence of the one God, while the other names reveal general or specific ways in which he acts providentially. ${ }^{5}$

The author of the Corpus Dionysiacum thinks that each term in the triad should not be thought of as separate hypostases, individualized as three separate Godheads. Pseudo-Dionysius's collapsing of the different terms of the triad, which for Proclus denoted different Gods, into different names of a single God is consonant with his strategy to collapse the first and second hypotheses from the Parmenides, the One and the One-Many, into a single God. This is one of the most important strategies that the author of the Corpus Dionysiacum employs for Christianizing the metaphysics of the Athenian school of Neoplatonism.

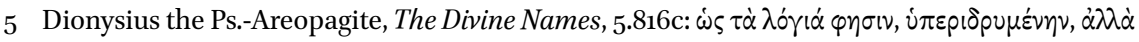

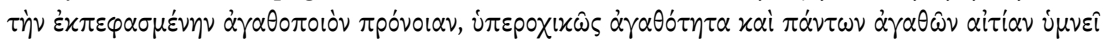

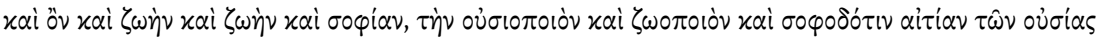

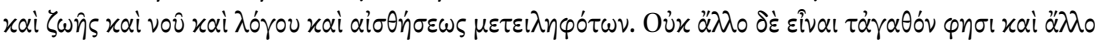

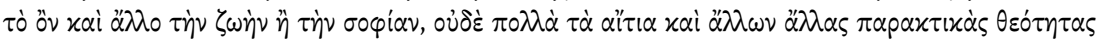

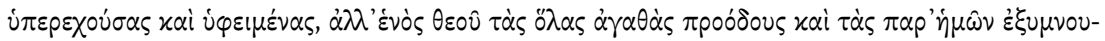

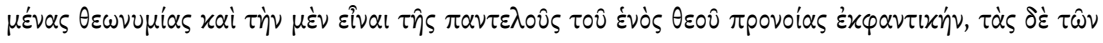

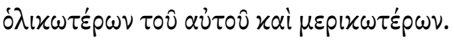


It is equally well known that Kaläm fi-mahd al-khayr (The Discourse on the Pure Good), which circulated in Gerard of Cremona's Latin translation as (c. 1114-1187) the Liber de causis (it was also copied with the title Liber de expositione bonitatis purae), is heavily indebted to Proclus, especially his Elements of Theology, while also incorporating reworked paraphrases of Plotinus. Therefore, it is also unsurprising that, along with the Corpus Dionysiacum, the Liber de causis became maximally important for theologians, not least of all because of its explanation of the nature of the divine first principle with the help of the triad being-life-intellect. It is now thought that a circle of Greco-Arabic translators (probably Christians who might have used Syriac) around the important Islamic philosopher al-Kindī (c. 8o1-873) produced this work in ninth-century Baghdad. They stripped their work of all references identifying it with Proclus and Plotinus, and purified it of most arguments that Christians and Muslims would consider pagan. ${ }^{6}$ The triad being-life-intellect is operative in the Liber de causis from the very first proposition, and it is interesting to note that one of the strategies employed by the Kaläm fi-mah d al-khayr and its Latin translation is analogous to the one used by the author of the Corpus Dionysiacum, namely to collapse the separate terms of the triad into different names for a single God. For instance, the exposition of Proposition 4 of the Liber de causis, "Prima rerum creatarum est esse et non est ante ipsum creatum aliud," claims:

Et esse quidem creatum primum est intelligentia totum verumtamen intelligentia in ipso est diversa per modum quem diximus. Et quia diversificatur intelligentia fit illic forma intellectibilis diversa. Et sicut ex forma una propterea quod diversificatur in mundo inferiori proveniunt individua infinita in multitudine similiter ex esse creato primo propterea quod diversificatur apparent formae intellectibiles infinite. Verumtamen quamvis diversificentur non seiunguntur ab invicem sicut est seiunctio individuorum. Quod est quoniam ipsae uniuntur absque corruptione et separantur absque seiunctione quoniam sunt unum habens multitudinem et multitudo in unitate. ${ }^{7}$

In short, like the Corpus Dionysiacum, the Liber de causis maintains that although being and intellect are different they remain unified and are not separate individuals. Therefore, despite being two of the most important channels to communicate Proclean metaphysics to the Latin Middle Ages, these two

6 Cf. Taylor 1986; Taylor 1989; D’Ancona 1995; D’Ancona 2014; Calma 2016, Calma 2019.

7 Liber de causis, prop. 4. 
works appropriated and handed down a reworked version of Proclus's understanding of the triad being-life-intellect that was forced to serve the needs of Abrahamic monotheistic theologians.

Medieval schoolmen thus inherited from the Corpus Dionysiacum and the Liber de causis the strategy of differentiating the terms in the triad while refusing to separate them as individuals. None other than Thomas Aquinas (12251274) is especially concerned to adopt this method for employing the triad being-life-intellect. For example, when Aquinas writes his commentary on the De divinis nominibus sometime between 1261-1268 he is aware of the general Platonic nature of Pseudo-Dionysius's arguments, including the fact that Pseudo-Dionysius supposedly thinks that in equating being, life, and intellect as intelligible realities the Platonists commit a mistake of polytheism. In his commentary on De divinis nominibus 5, Aquinas argues that the triad should not be thought of as something like separate Platonic forms, or even worse individual Gods, but as divine names of a single God:

Deinde, cum dicit: non autem et cetera, excludit errorem quorumdam Platonicorum qui universales effectus in intelligibiliores causas reducebant. Et quia videbant effectum boni universalissimum esse, dicebant suam causam esse ipsum bonum quod effundit bonitatem in omnia, et sub ea ponebant aliam causam quae dat vitam et sic de aliis et huiusmodi principia dicebant deos. ${ }^{8}$

By 1268 Aquinas had received a copy of the archbishop of Corinth William of Moerbeke's (c. 1215/35-c. 1286) translation of Proclus's Elements of Theology and realized that the Liber de causis largely had its origins in Proclus. Why Aquinas sees the dependence of the Liber de causis but not the dependence of the Corpus Dionysiacum on Proclus remains to be considered, but the belief in PseudoDionysius's apostolic authority probably impressed itself on his judgment with the greatest severity. ${ }^{9}$ In any case, when Aquinas writes his commentary on the Liber de causis just a few years later in 1272 he is much more specific about the Platonic mistake that Pseudo-Dionysius avoids in his De divinis nominibus. He refers once again to De divinis nominibus 5 to explain that Platonists naively think that God created the world according to ideas separate from the divine

8 Thomas Aquinas, Super De divinis nominibus, 5.1.

9 On Thomas Aquinas and Dionysius see Hankey 1997 and O'Rourke 2005. On Aquinas and the Platonists see Thomas Aquinas, Super Librum de causis exposition and Henle 1956, and Hankey 2002. On the circulation of doubts about the authenticity of the Corpus Dionysiacum in the fifteenth and sixteenth centuries see Robichaud 2021a and Robichaud 2021b. 
intellect, but having now read Proclus's Elements of Theology, he also specifies that Platonists follow Proclus in particular by deifying being, life, and intellect as Gods. ${ }^{10} \mathrm{He}$ makes a very similar argument in the De substantiis separatis from c. $1271 .^{11}$

Despite the more sophisticated analysis of his commentary on the Liber de causis, Aquinas's understanding of ancient Platonism is still vague at best. What would it mean to say that the Platonic God, the Demiurge, created the world from pre-existing ideas of being, life, and intellect, especially if these ideas are really other Gods? One does not find a clear or developed answer in Aquinas. When Marsilio Ficino (1433-1499) asked himself this question in his twenties, like Aquinas he turned to Proclus's writings for an answer, but unlike Aquinas Ficino did not just read the Elements of Theology, he also studied Proclus's massive Platonic Theology and his voluminous commentaries on Plato's dialogues, and devoted himself to understanding Iamblichus's philosophy by first studying the De secta Pythagorica, and eventually the De mysteriis. Ficino further studied later Platonic philosophers including Hermias, Priscian of Lydia, and Damascius (the lecture notes to the Phaedo and the Philebus, which Ficino attributed to Olympiodorus), and the Emperor Julian. The results of Ficino's intellectual labor not only clarifies the traditional theological strategy of differentiating the terms of the triad being-life-intellect without splitting them into separate substances or Gods, it also explains Proclus's position by uncovering a critical disagreement among late ancient Platonists over the triad's relationship to demiurgy.

If one were to restrict one's understanding of Proclus solely to the Elements of Theology the picture of his philosophy that one would attain would be quite different from the image that emerges from Proclus's commentaries on Plato, his hymns, and especially his Platonic Theology. Indeed, ancient poetic theogonies, Chaldean Oracles, theurgy, Pythagoreanizing tendencies to explain mathematics and first principles, as well as myths, tropes, arguments, and quotations from the wealthy storehouse of Plato's corpus, and most importantly for my present discussion, a theology of the Hellenic Gods is comparatively much less present in the Elements of Theology than in Proclus's other works. While the Platonic

10 Thomas Aquinas, Super Librum de causis expositio, lectio 3.

11 Thomas Aquinas, De substantiis separatis, cap. 1. 
triad of being-life-intellect was a central feature in the Corpus Dionysiacum, in the Liber de causis, and in numerous other Medieval theologians' writings about the Christian God, readers of Proclus's Platonic Theology would immediately recognize that the same divine names that Pseudo-Dionysius applies to the Godhead in De divinis nominibus and that the Liber de causis examines are also Proclus's organizing principles for the Greek Gods. As Aquinas eventually realized, Proclus mentions this in the Elements of Theology, but there Proclus does not go into as many details about specific deities as he does in the Platonic Theology.

Ficino is famous today largely because he is the first person to produce full Greek to Latin translations of and commentaries on Plato's complete works and Plotinus's Enneads, but Ficino was also an avid student of Proclus. ${ }^{12}$ I have recently studied manuscript fragments and evidence for Ficino's now lost translations of Proclus's Elements of Theology and Elements of Physics and argued that some of his first forays into Platonism emerged from studies of the use of proposition 15 of the Elements of Theology in scholastic commentaries on Aristotle's De anima when he was about 20 years old (c. 1453-1454). ${ }^{13}$ Ficino eventually translated and published large portions of Proclus's Commentary on the First Alcibiades, and the entirety of the De sacrificio et magia. He was also the first reader in the Latin West of Proclus's Commentary on the Republic, which he seems to have gotten his hands on as soon as Janus Lascaris brought the manuscript to Lorenzo de' Medici from Mount Athos in 1492. He then published his Latin translation of a fairly large excerpt of it within a month of examining the manuscript. Ficino also mentions that in his youth he translated Proclus's hymns but burned them. In addition to these translations, Ficino studied Proclus's Commentary on the Parmenides, his Platonic Theology, his On Providence, On Fate, and On the Existence of Evil. Late in life, Ficino translated and wrote commentaries on Pseudo-Dionysius's De divinis nominibus and De mystica theologia in which he deploys the fruits of his labors studying Proclus. In short, from his first engagements with Platonism until his last philosophical and scholarly works Ficino was an enthusiastic student of Proclus.

12 There is now a healthy bibliography on Ficino and Proclus. See: Allen 1986; Allen 2014; Beierwaltes 2002; Copenhaver 1988; Étienne 1997; Gentile 199o; Gersh 2014, p. 1-29; Klibansky 1943, p. 281-330; Klutstein 1987; Kristeller 1987, now in Kristeller 1984-1986, vol. 4, p. 115-137; Lazzarin 2003; Malmsheimer 2001; Megna 2003, Megna 2004; Rabassini 1999; Saffrey 1959, now in Saffrey 2002, p. 69-94; Sanzotta 2014; Steel 2013; Steel 2014; Robichaud 2016; Robichaud 2017a; Robichaud and Soranzo 2017; and Marsilio Ficino, Commentary on Plato's Parmenides; Id., Commento al Parmenide di Platone. 
We are fortunate that some of Ficino's notes on Proclus's Platonic Theology survive (Figure 1). ${ }^{14}$ In a comprehensive set of notes, which he entitles Ordo divinorum apud Platonem secundum Proclum, Ficino outlines the complete structure of Proclus's theology, detailing the series of Gods, ordered according to their theological principles being-life-intellect.

These notes document how Ficino correctly reconstructs Proclus's hierarchical metaphysics. Presiding over the whole theological series is the superessential and unparticipated One. There then follows the henads (or unities), the first triad of intelligible Gods, which as a whole corresponds to the principle of being, and is composed by limit and unlimited to form the triad of intelligible being, intelligible life, and intelligible intellect. Ficino continues to explain the second triad of intelligible-intellective Gods, which proceeds from the first, and as a whole corresponds to the theological principle of life. He then turns to the third order in the procession of Proclus's theology, the intellective Gods, which as a whole corresponds to the principle of intellect. I quote Ficino who employs the Latin names of the deities:

After this intellect follows and is divided by essence into seven intellects, which participate by essence as unities in life and being. The first intellect is Kronos (Saturnus); the second is Rhea (Ops), in which there are three fonts, namely the crater of souls, the font of virtues, and of nature; the third is Zeus (Iuppiter), the first Demiurge of the intellectual world in which the second exemplars are located, namely the intellectual exemplars, since the first are the intelligible exemplars. These three intellectual parts correspond to three intellective Gods, the guardians and Kouretes. $^{15}$

In these notes Ficino has written a concise but absolutely accurate account of Proclus's theology, explaining that below the One, Proclus derives the Hel-

14 Saffrey first suggested in 1959 (now 2002, p. 161-184) that Ficino studied Proclus's Platonic Theology by 1463 , that is before he turned 30 , and I have recently confirmed this hypothesis in Robichaud 2018, p. 149-186.

15 Marsilio Ficino, Ordo divinorum apud Platonem secundum Proculum, ms Florence, Biblioteca Riccardiana 70, f. $2^{\text {r }}$. Saffrey has edited the text (Saffrey 2002, p. 171): Sequitur post intellectus per essentiam discretus in septem intellectus per essentiam participantes vitam, ens, unitates. Primus intellectus est Saturnus, secundus Opis in qua sunt tres fontes, scilicet patera animarum, fons virtutis et nature, tertius Iupitter primus mundi opifex qui est mundus intellectualis in quo sunt secunda exemplaria, scilicet intellectualia, cum prima sint intelligibilia. His tribus partibus intellectualibus correspondent tres dee intellectuales custoditive et curitiche. 


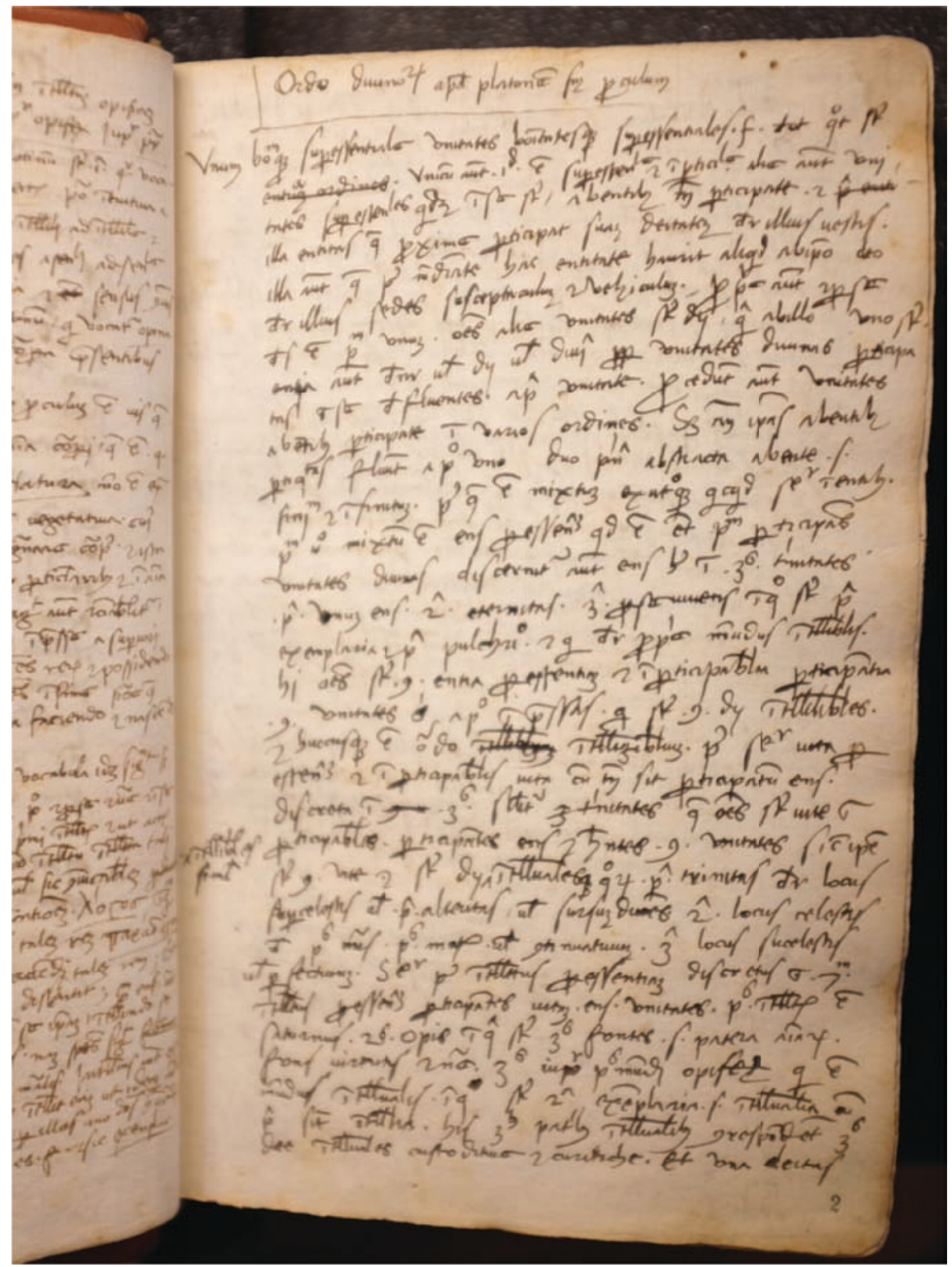

FIGURE 1

Ficino's Notes to Proclus' Platonic Theology: Ms. Florence, Biblioteca Riccardiana, 70, f. $2^{\mathrm{r}}$ 
lenistic Gods from the henadic principles of limited and unlimited according to the triad being-life-intellect. Following Iamblichus's law of the mean terms, each of the three terms then proceeds or unfolds as a second triad according to the same three terms. For instance, the last term of the series, the intellect, which corresponds to the intellective Gods, itself unfolds into Kronos (being), Rhea (life), and Zeus (intellect). For this precise genealogy Proclus is in all likelihood following Iamblichus's interpretation of Plato's Timaeus (40e-41a). Ficino's notes reveal that he did not just skim Proclus's Platonic Theology, since he would have had to have read well into Book 5 to find the passage detailing the genealogy of the Gods that I just quoted. ${ }^{16}$ Ficino's impressive and precise reconstruction of Proclus's theology (Figure 2) demonstrates that he comes to understand how Proclus conceives of the triad being-life-intellect, which Ficino and his contemporaries would have already known as long-established divine names for the Christian God, to name the Gods Kronos, Rhea, and Zeus. Ficino's understanding of the Platonic triad is no longer limited to Aquinas's vague notion of Platonic ideas and anonymous Gods. His reading of Proclus discovers that being, life, and intellect are divine names of specific individual Gods. Ficino uncovers, moreover, that Proclus actually speaks about different levels of demiurgy. The highest Demiurge is the lowest term of the transcendental intellectual triad and corresponds to Zeus in the theogony following Kronos and Rhea. This is "the maker and father" of Plato's Timaeus (28c). Its lower hypercosmic half, according to Proclus, is the Demiurge in the triad Zeus, Poseidon, Hades from the myth of the Gorgias (523a). Once more following Iamblichus's law of mean terms, the connection of these two levels is symbolized by the fact that Zeus is the lowest term in the transcendental triad but the highest term in the hypercosmic triad. Proclus thereafter represents how demiurgy unfolds into the lowest ontological levels of nature by identifying Dionysus as the demiurgic God connecting the hypercosmic and the encosmic young Gods mentioned by Plato in Timaeus (42d), and even possibly postulating Adonis as the lowest manifestation of this procession. ${ }^{17}$

Ficino is aware of the multiple manifestations of Demiurge-Zeus in this Platonic system, writing in his notes Ordo divinorum apud platonem secundum Proclum:

16 Proclus, Platonic Theology, 5.3.

17 For an overview of Proclus's hierarchical theology see especially Saffrey and Westerink's introduction to Proclus, Platonic Theology, p. ix-lxxxix. For demiurgy in this system see Opsomer 200o; Opsomer 2001; Opsomer 2003; Opsomer 2005; Opsomer 2017; d'Hoine 2008; Dillon 2000. See also the discussion in the introduction of Van Riel 2008. For a dis- 
Iamblichus, Syrianus, Proclus et al.

- One

- Henads (limit and unlimited)

- Transcendent Gods

- Intelligible (Being)

- Intelligible-Intellective (Life)

- Intellective (Intellect)

Essential Intellect (Being) = Kronos

Living Intellect (Life)

Intellective Intellect (Intellect)

$=$ Rhea

Athena, Kore, Kouretes, Seventh Divinity (Guardians)

- Hypercosmic Gods

- Demiurgic Triad

$=$ Zeus

Zeus (Being/Essentia)

Poseidon (Life/Vita)

Hades (Intellect/Species)

- Vital Triad

$=$ Kore

Artemis

Persephone

Athena

- Guarding and Converting Triads of the Korybantes and Apollo

- Hypercosmic-Encosmic Gods

- Encosmic Gods

- Universal Souls

- Angels, Demons, Heros etc.

FIGURE 2 Schema of relevant details of Ficino's reconstruction of Proclus's Platonic Theology

But after the Demiurge-Zeus (Opifex Iuppiter), who is the boundary of the whole partial realm and the father of all that follows, there flow from him three orders of the partial Gods, who are intellects but participated intellects, since there were seven unparticipated intellects. The first order is called the hypercosmic, assimilative, ruler, and leader; the second is called imperishable and intermediary; the third is called encosmic and young.

cussion of the theological sources present in this system see also Brisson 1987; Brisson 2017, and the table provided by him and Van Riel that follows on p. 323-328. On Ficino and Iamblichean mean terms see Robichaud 2020. 
And since only the first Demiurge (primus opifex) himself governs alone the whole encosmic realm and gives all to all, these three orders divide the work [of demiurgy]. The first order gives parts to all, the second all to parts, and the third parts to parts. ${ }^{18}$

Following Proclus's Platonic Theology and commentary on the Timaeus, Ficino has just distributed demiurgic causality accurately between the single Demi-

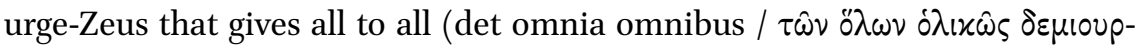
$\gamma(x \dot{0})$ ), and the demiurgic triad of causality that gives parts to all (dat partes

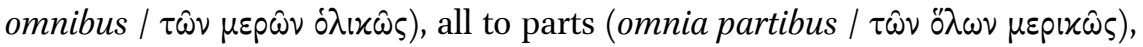
and finally parts to parts (partes partibus / $\tau \hat{\omega} \nu \mu \varepsilon p \hat{\omega} \nu \mu \varepsilon p(x \hat{\omega} \varsigma) .{ }^{19}$ Ficino continues to explain Proclus's theology:

The first dozen are divided into four trinities. The first trinity is Saturnian because it is after the first Zeus (Iuppiter primus) under the ratio of Kronos (Saturnus), and the first in that trinity is called Zeus (Iuppiter), second Poseidon (Neptunnus), third Hades (Pluto), because they act separately insofar as Demiurge-Zeus (Opifex Iuppiter) is one; the first gives essences (essentiae), the second lives (vitae), the third forms (species). The second trinity pertains to life and as a whole is called Kore (Proserpina), but the first of its unities is Artemis (Diana), the second is Persephone, and the third is Athena (Minerva). This trinity is guarded on its border by a trinity of protection and a trinity of conversion, ${ }^{20}$ which are called the Goddesses Korybantes, and just as the Kouretes accompany Rhea (Ops) so do the Korybantes accompany Kore (Proserpina). But the third trinity in

18 Marsilio Ficino, Ordo divinorum apud Platonem secundum Proculum, Ms Florence, Biblioteca Riccardiana 7o, f. $2^{\mathrm{v}}$ (cf. Saffrey 2002, p. 172): Post opificem vero Iovem qui est confinium totalium particulariumque et pater omnium sequentium, fluunt ab eo tres ordines deorum particularium, qui sunt intellectus sed tamen participati, cum illi septem fuerint imparticipabiles intellectus. Primus ordo dicitur supermundanus, assimilativus, dux, prince $\langle p\rangle$; secundus medius indissolubilisque; tertius mundanus et iuvenis. Et cum primus opifex ipse solus omnia mundana gubernat et det omnia omnibus, tres isti ordines dividunt opus: et primus ordo dat partes omnibus, secundus omnia partibus, tertius partes partibus.

19 See Proclus's In Timaeum, 309.14-312.26, but all of In Timaeum, 299.13-327.10 and Book 6 of the Platonic Theology is very relevant for this material. See also for example, the discussion in Opsomer 2001, p. 53-54.

20 Saffrey transcribed this correctly as conservativa, though I'm inclined to read this as convertiva or conversiva since below Ficino employs conversiva, corresponding to the Neopla-

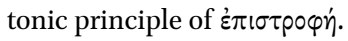


the linear series (in ordine lineari) pertains to conversion and is called as a whole Helios or Apollo (Solvel Appollo). The order (ordo) of hypercosmicencosmic Gods follow. ${ }^{21}$

Ficino thus grasps the complete ordering system of Proclus's theology, first, as it unfolds, following the Iamblichean law of mean terms, the triad being-lifeintellect into further triads of being-life-intellect identified with linear series of separate Gods, and second, as Demiurge-Zeus communicates its work down a processive series to lower demiurgic activities. Ficino even notes how Proclus completes the series by identifying Plato's young Gods (Timaeus 42d) with the encosmic Gods ruling over the four elements, followed by daemons, angels, and heroic souls, and how Proclus separates Demiurge-Zeus from the object of his contemplation, the paradigm of the absolute living being from Timaeus (39e), saying:

However, the Demiurge who is the Intellect of the Intellective Gods, when he contemplates on high in this intelligible intellect, since it is its exemplar, makes the cosmos according to the exemplar of the henadic forms (forme unius), which he sees in that comprehension. ${ }^{22}$

However, to comprehend the ancient relationship between Christian and Platonic triads, Ficino pays special attention to the fact that Proclus identifies

21 Marsilio Ficino, Ordo divinorum apud Platonem secundum Proculum, Ms Florence, Biblioteca Riccardiana 7o, f. $2^{v}$ (cf. Saffrey 2002, p. 172): Sunt autem primi duodecim distributi in quattuor trinitates. Prima trinitas est Saturnalis, quia fit ab Iove primo sub ratione Saturni; et primus in ea trinitate dicitur Iuppiter, secundus Neptunnus, tertius Pluto, quia divisim agunt quod opifex Iuppiter unus, primus dat essentias, secundus vitas, tertius species. Secunda trinitas est vitalis et tota dicitur Proserpina, prima vero illius unitas Diana, secunda Persefogni, tertia Minerva. Hanc autem trinitatem ex latere comitatur trinitas custoditiva et conservativa, que dicuntur dee corivandes et sicut supra curitiche fuerunt circa Opim sic circa Proserpinam chorivandes. Tertia vero trinitas in ordine lineari est conversiva et dicitur tota Sol vel Appollo. Sequitur ordo deorum qui supermundani mundanique simul.

22 Marsilio Ficino, Ordo divinorum apud Platonem secundum Proculum, Ms Florence, Biblioteca Riccardiana 70, f. $3^{\mathrm{r}}$ (cf. Saffrey 2002, p. 173-174): Secuntur dii mundani qui dicuntur dii iuvenes, qui habent quattuor exercitus. Primus habitat a primo celo et post per speram ignis sub celo usque ad principium aeris; secundus aerem usque ad dimidium; tertius hinc usque ad terram; quartus terram. His respondent ordinatim quattuor ordines angelorum, quattuor demonum et quattuor animarum. Unde in unaquaque quattuor partium mundi sunt quattuor ordines spirituum, qui sunt facti a primo opifice Iove sic. Opifex autem, qui est intellectus intellectualis, cum aspicit sursum in hoc intellectu intelligibili ut ad eius exemplar, fabricet mundum ad exemplar forme unius, quam in illo conceptam videt. 
Zeus as the Platonic Demiurge, or the world's maker, and that the first ZeusDemiurge (in the procession of demiurgic activity identified above) is the lowest term in the Intellective triad being-life-intellect, which as a whole corresponds to the lowest term of a prior triad being-life-intellect that corresponds to Intelligible (Being), Intelligible-Intellective (Life), and Intellective (Intellect) (see Figure 2). We find Ficino on the hunt for this Demiurge-Zeus, which he designates as primus mundi opifex, proximus intellectus, and proximus mundifaber, in his studies of Plotinus's Enneads.

Finding the Demiurge in Plotinus, Porphyry, Iamblichus and Proclus

The Platonic Demiurge became a subject of intense focus in Ficino's thinking. ${ }^{23}$ In scrutinizing Proclus's commentary on the Timaeus Ficino learned that there was actually a vocal disagreement among late ancient Platonists regarding Plato's Demiurge. The problem resembles a Russian doll: Ficino's study of Iamblichus and Proclus's critique of Porphyry's interpretation of Plotinus's understanding of Plato's Demiurge. In order to make sense of the controversy among ancient Platonists regarding Plotinus's understanding of the Demiurge, when Ficino studies Plotinus's Enneads, he takes note in the margins of his Greek manuscript of instances where Plotinus speaks of the Demiurge. The first passage of interest to Ficino is Enneads, 2.9.6, Against the Gnostics. After critiquing the Gnostic Christians for dividing reality into multiple suborders of beings and misinterpreting Plato, Plotinus admonishes them:

And the making a plurality in the intelligible world, Being, and Intellect, and the Maker different from Intellect, and Soul, is taken from the words in the Timaeus: for Plato says, "The maker of this universe thought that it should contain all the forms that intelligence discerns contained in the Living Being that truly is.' (Tim. 39e 7-9). But they did not understand, and took it to mean that there is one mind which contains in it in repose all realities, and another mind different from it which contemplates them, and another which plans - but often they have soul as the maker instead of the planning mind - and they think that this is the maker according to Plato, being a long way from knowing who the maker is. ${ }^{24}$

23 Cf. Allen 1987.

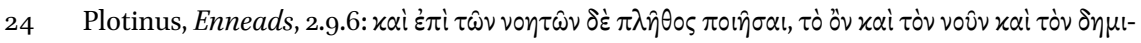




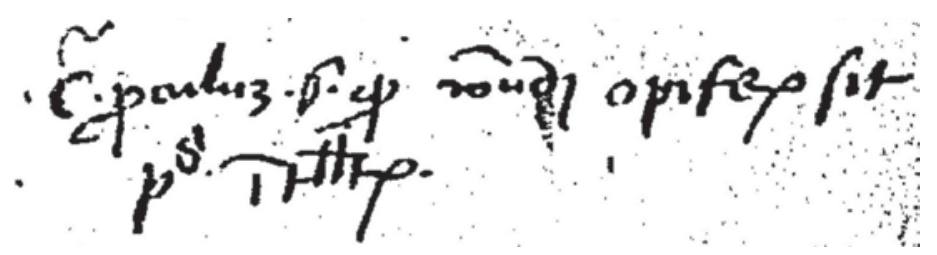

FIgURE 3 MS. Paris, Bibliothèque nationale de France, Gr. 1816, f. $75^{\mathrm{r}}$

In the margins of this passage Ficino writes succinctly, "Against Proclus, namely that the maker of the cosmos is the last (or nearest) intellect." (Figure 3$)^{25}$

Following Iamblichus, Proclus departs from Plotinus's conception of the Demiurge by postulating a triad for the Intellect below the One and the henads: the Intelligible, the Intelligible-Intellective, and the Intellective, of which each term is identified respectively with being, life, and intellect. In Proclus's account of the Timaeus, the Demiurge proper is in the lowest member in the Intellective triad (composed of the Essential Intellect, the Living Intellect, and the Intellective Intellect). Therefore, Proclus identifies the Demiurge as the Intellective Intellect and also names him Zeus (he names the prior two terms Kronos and Rhea). Ficino rightly notes Zeus-Demiurge as "proximus" designating the nearest or lowest ontological reality of Intellect, the neighboring part to the lower realm.

Unlike common Christian assumptions that there is an absolute ontological chasm between creator and creature, Neoplatonists do not argue for a creatio ex nihilo nor for an absolute division between the divine Intellect and the world below it, rather the cosmos emanates from the divine, and always remains in contact with it. To be sure, Neoplatonists like Proclus also argued for the radical transcendence of everything above the cosmos, but Proclus's transcendence was always mediated by the Iamblichean notion of a third 'mean term.'

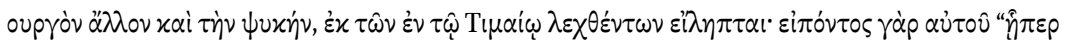

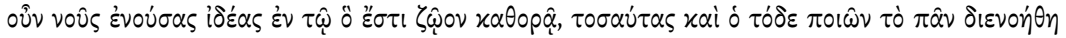

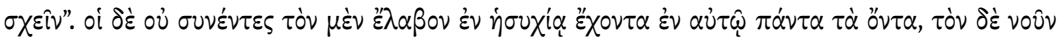

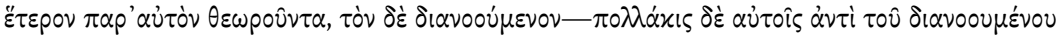

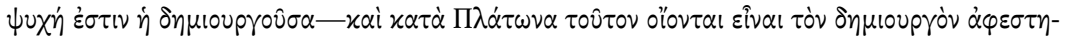

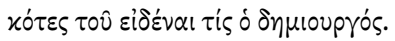

Ms Paris, Bibliothèque nationale de France, Gr. 1816, f. $75^{\mathrm{r}}$ : Contra Proculum scilicet quod mundi opifex sit proximus intellectus. On Ficino and this manuscript see Henry 1948, p. 4562, 45-62; Gentile, Niccoli, Viti 1984, p. 21, 122; Förstel 2006 (who is also finishing an edition of Ficino's complete notes to the manuscript); Robichaud 2016; Robichaud 2017a; Robichaud 2017b; Robichaud 2018, p. 224-229. 
For instance, according to Proclus, between the Hypercosmic Gods and the Encosmic Gods there are the Hypercosmic-Encosmic Gods. In order to protect the transcendence of the Demiurge-Zeus and following the myths about Zeus's protectors, Proclus introduces the Kouretes as Zeus's guardians along with a seventh deity, identified as the membrane or boundary between the Intellective and Hypercosmic realms. However, insofar as Proclus's Demiurge is the lowest term in the triad Kronos-Rhea-Zeus, he is also the boundary between the Intellective and Hypercosmic levels of reality. As such, moreover, he is not only the last term, but also a mean term between these two levels of reality. Such is the logic of Proclus's understanding of the divine. In short, whereas a Christian understanding of demiurgy as creatio ex nihilo proposes an absolute incommensurability between creator and creature and situates cause and effect on two separate ontological levels, Proclean demiurgy is precisely about the stratification of reality according to the liminal contact of mean terms. Why then would Ficino take note of the fact that Plotinus's arguments about the Demiurge in Enneads, 2.9.6, Against the Gnostics go against Proclus?

Plotinus's criticism of the Christian Gnostics is directed at the fact that they make strong demarcations between different substances, most importantly that they divide the Intelligible world into a plurality of substantial forms held in a mind distinct from the Intellect that contemplates them, and that they argue for an ontological dualism composed of an evil dead matter and a good living spirit. Plotinus confirms his emanative philosophy by appealing to Plato's ontology from the Sophist (248e-249a) precisely to argue that being is not dead matter but also contains life and intellect. In the passage quoted above, he also critiques the Gnostics for misunderstanding what Plato says in Timaeus 39e, believing that Plato states that the paradigm of the absolute living being is held in a separate mind from the Demiurge's contemplative mind. This position alone contradicts Plotinus's understanding of the Demiurge since Plotinus holds that because Intellect is identical to its thoughts, the paradigms should not be thought to exist in a mind separate from the intellect that contemplates them. Specifically, Ficino's notes reveal that he finds certain similarities between the Gnostic Christians and Proclus regarding the stratification of the Intellect into a hierarchical order. More generally, Ficino's interest in locating the Demiurge and the lowest or neighboring Intellect (proximus intellectus) in Neoplatonic texts is an attempt to find the point where the Intelligible first touches our cosmos, in Christian terms the instance when God's hand creates.

For his part, Proclus reasons that Plotinus is correct in situating the Demiurge in Intellect, yet Proclus departs from him to the degree that he follows 
Iamblichus in multiplying the ontological levels of Intellect into fully formed triads, and precisely in situating the Demiurge on the lowest border. If Proclus found something of value in Plotinus's discussion of the Demiurge, he disagrees quite strongly with Porphyry's judgment (as he presents it his Timaeus commentary) that the Demiurge is not found on the noetic level but in Soul. The question revolves around the correct interpretation of Timaeus 39e, quoted above. Proclus inquires in his commentary on the Timaeus:

Thinking that he is in agreement with Plotinus, Porphyry calls the soul the hypercosmic demiurge on the one hand and its Intellect, to which it has turned, the Living-Thing-itself ( $\alpha \dot{v} \tau 0 \zeta \omega \mathrm{\omega} v$ ) on the other, so that in his view the paradigm of the demiurge is the Intellect. It is worth asking him in which text Plotinus makes the soul a demiurge. ${ }^{26}$

Ficino takes up Proclus's challenge and responds in the margins of his Plotinus manuscript.

Traces of Ficino's search for a passage where Plotinus discusses the Demiurge as Soul are visible in his manuscript of the Enneads. They first appear in the final chapter of Enneads, 2.3.18, On Whether the Stars are Causes, where Plotinus argues that if something is thought to be evil, a poisonous snake for example, its existence contains an unobservable good. He mentions that a perceived evil can cause beautiful art or make us reflect on our way of life-to which Plotinus says "If this is correct, it must be that the Soul of the all contemplates the best, always aspiring to the intelligible nature and to God, and that when it is full, filled right up to the brim, its trace, its last and lowest expression, is this productive principle that we are discussing. This, then, is the ultimate maker; over it is that part of soul which is primarily filled from Intellect: over all is Intellect the Craftsman, who gives to the soul which comes next those gifts whose traces are in the third." ${ }^{27}$ Next to this passage, and below a

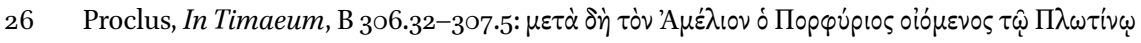

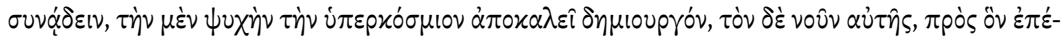

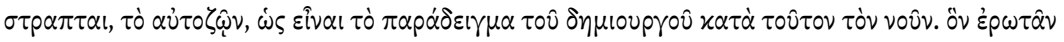

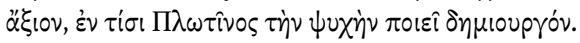

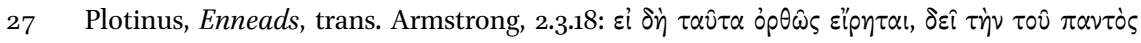

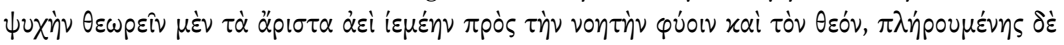

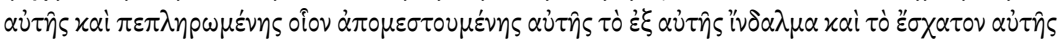

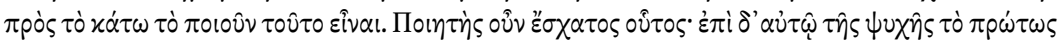

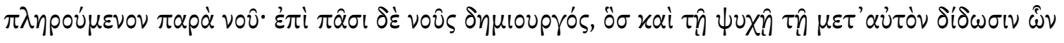

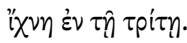




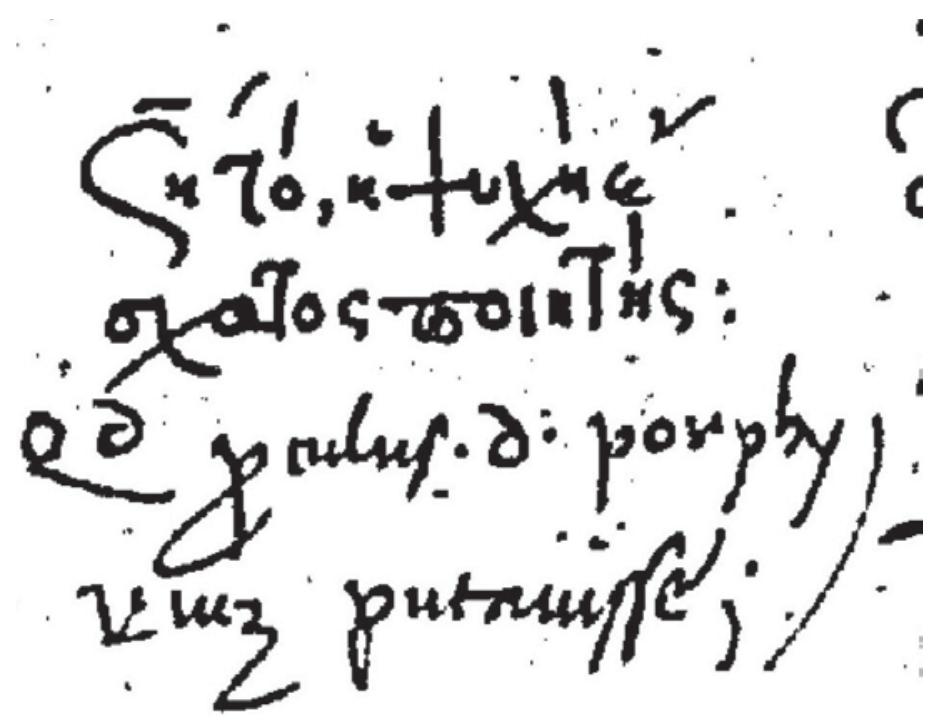

FIgURE 4 MS. Paris, Bibliothèque nationale de France, Gr. 1816, f. $59^{\mathrm{v}}$

Greek manuscript scholion indicating "Nota Bene: the soul is the ultimate maker (or lowest Demiurge)," Ficino's note says, "Proclus says that is what Porphyry thought." 28 (Figure 4)

Indeed, this passage from the Enneads is tantalizingly close to being evidence for Proclus's understanding of Porphyry's opinion that the Demiurge is Soul instead of Intellect, insofar as the ultimate maker or the Поэंทेऽ oûv है $\sigma \chi \alpha-$

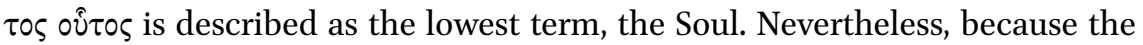

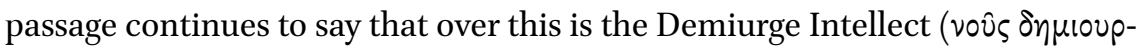
rós) it does not fully justify Porphyry's interpretation (as Proclus characterizes or, as some might say, mischaracterizes it). ${ }^{29}$

Ficino, however, did find a passage that agrees with Proclus's account of Porphyry's reading of Plotinus's Demiurge. The text in question is Enneads 3.2.16, On Providence, where Plotinus responds again to the theodical question about evil, asking how there can be injustice when all things are ordered with providence. After answering that such complaining is akin to a poet writing a dialogue for a character in a play who insults the play's author, Plotinus breaks off boldly as follows:

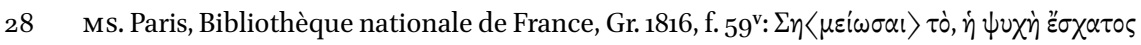

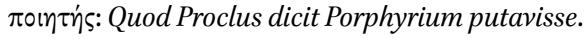

29 Cf. Dillon 1969; Deuse 1977; Monet 20oo; Opsomer 2005. 
Let us, then, again, and more clearly, explain what the rational forming principle of our universe is and that it is reasonable for it to be like this. This rational principle, then, is - let us take the risk! We might even, perhaps succeed [in describing the Demiurge] - it is not pure intellect or absolute intellect; it is not even of the kind of pure soul but depends on soul, and is a sort of outshining of both; intellect and soul (that is, soul disposed according to intellect) generated this rational principle as a life which quietly contains a rationality. ${ }^{30}$

It is with this passage - where Plotinus explains the fabrication of the cosmos with the principles of being, life, intellect-that Ficino responds to Proclus's demand for textual evidence of Porphyry's interpretation of Plotinus's understanding of the Demiurge as Soul. As a gloss to the passage, Ficino refers back to Plato's Timaeus and writes in both Greek and Latin (Figure 5):

The logos emanates from intellect and soul into matter. The cosmos is a mixture of mind and necessity. Porphyry says that the closest (proximus, last or nearest) Demiurge of the world is the soul, as Proclus maintains in his commentary to the Timaeus! Which is what Plotinus seems to intend. ${ }^{31}$

Contrary to Proclus, Ficino believes to have found textual evidence for Porphyry's interpretation that Plotinus thinks that the Demiurge (understood as the operation of a formative logos) is located in Soul (disposed according to Intellect). In another section entitled Proprietas vocabulorum Platonicorum from the notes appended to his manuscript of Proclus's Platonic Theology that I discussed above, Ficino once more comments on the twofold nature of Plotinian demiurgy:

Zeus, as Plotinus says in the second book of doubts on the soul [Enneads, 4.4.10], has a twofold signification: at one time the Demiurge-Intellect, at

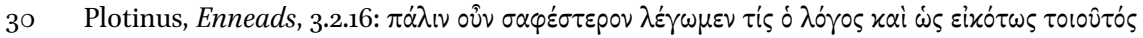

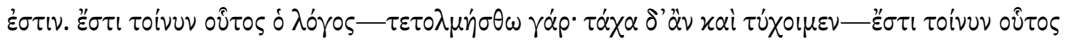

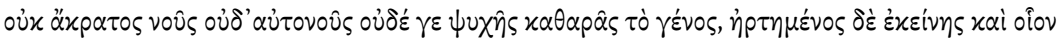

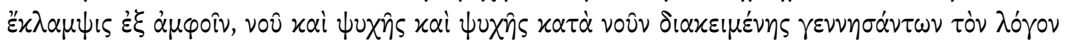

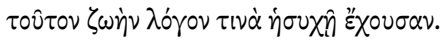

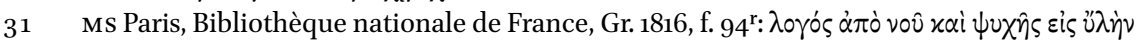

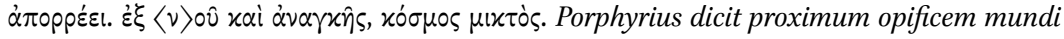
esse animam, ut Proculus testatur in Timeo: Quod et Plotinus velle videtur. 


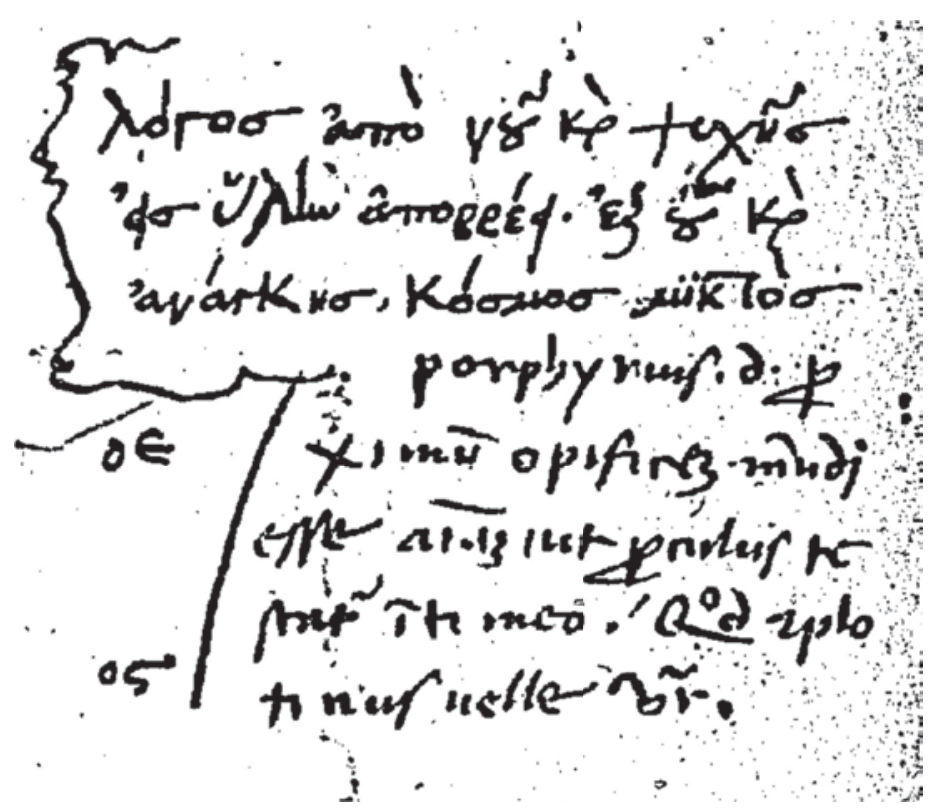

FIGURE 5 MS. Paris, Bibliothèque nationale de France, Gr. 1816, f. $94^{\mathrm{r}}$

another time the World Soul, and he says that this Intellect is called the Demiurge-Zeus (Iuppiter opifex) and the Father-Zeus (Iuppiter pater), but the World Soul is called the Ruler-Zeus (Iuppiter dux). ${ }^{32}$

It is important to remember that Ficino's disentangling of the different Platonic interpretations of the Demiurge has a direct consequence on his understanding of how the triad being-life-intellect is employed in different hands to explain the divine. In fact, Ficino's printed commentary on Plotinus turns to Iamblichus's and Proclus's understanding of the Demiurge specifically because of the implications for understanding the theological principles of being-lifeintellect. Modern scholars of Plotinus often overlook the short treatise Enneads 3.9 , since the work is in reality a collection of philosophical notes, perhaps based on classroom discussions, but when they do, they follow Ficino's divi-

32 Marsilio Ficino, Proprietas vocabulorum Platonicorum, Ms Florence, Biblioteca Riccardiana 7o, f. $1^{\mathrm{v}}$ (cf. Saffrey 2002, p. 176): Iuppiter, ut dicit Plotinus libro secundo de dubiis anime, significat duo: aliquando intellectum opificem, aliquando animam mundi; et dicit quod ille intellectus vocatur Iuppiter opifex, Iuppiter pater, anima autem mundi dicitur Iuppiter dux. Cf. Plotinus, Enneads, 4.4.10. On this distinction see also Marsilio Ficino, Commentary on the Phaedrus, p. 111-121. 
sion of the work into nine separate considerations. ${ }^{33}$ Ficino is interested in this work since Plotinus explicitly addresses the nature and identity of the Demiurge. In fact, the first consideration in Enneads 3.9 is Plotinus's commentary to the lemma from Plato's Timaeus 39e (which Plotinus discussed, as noted above, in Enneads 2.9.6 Against the Gnostics): "Intellect," Plato says, "sees the Ideas existing in Life" then, he says, "the Demiurge planned that, what Intellect sees in Life, this universe too should have." ${ }^{34}$ Having established the presence of two terms of the triad-life and intellect—in this passage about the Demiurge from the Timaeus, Plotinus cites a passage from the Phaedrus $(247 \mathrm{c}-\mathrm{e})$ to introduce the third: "For there, Plato, says is truth too, in real being, where each and every thing in itself is." ${ }^{35}$ Plotinus inquires whether the Demiurge saw the ideas outside of his intellect. Scholars of Plotinus know that he argues quite strongly that the intelligibles are not outside of the intellect but are in fact identical to it. If Plotinus holds that the intelligbles are identical to the intellect, how then are they distinguished from one another if they are not separated, and specifically how will the principles of being-life-intellect themselves be distinguished from each other, especially if they correspond to individual Gods?

I quote Plotinus's solution:

Now, even if each is different from each other, they are not separate from each other except in so far as they are different. Further, there is nothing in the statement against both being one, but distinguished by thought

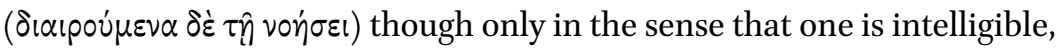
the other intellect. ${ }^{36}$

Here, Plotinus explicitly gives his thoughts on Plato's Demiurge, and maintains a strong form of the thesis that the Intellect is identical to its thoughts, which are differentiated rationally but not ontologically. This specific solution was

33 Cf. Dillon 1969; Deuse 1977; Monet 200o; Opsomer 2005, like Ficino before them, turn to this passage from the Enneads specifically to make sense of the debates between Iamblichus, Proclus, and Porphyry on the correct interpretation of Plotinus's understanding of the Demiurge.

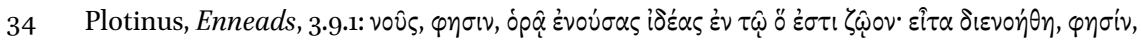

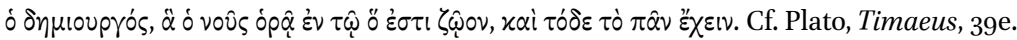

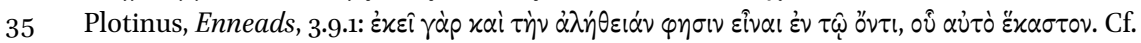
Plato, Phaedrus, $247 \mathrm{c}$.

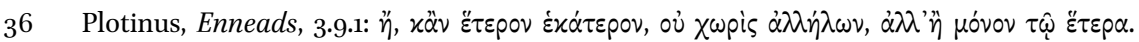

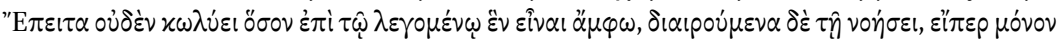

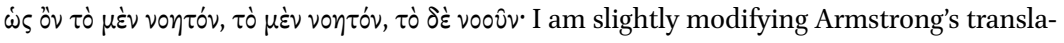
tion. 
extremely important for Ficino since it provides him with an alternative to Iamblichus's and Proclus's understanding of the Demiurge as a separate term in the triad being-life-intellect.

Here is Ficino's commentary on Enneads 3.9.1:

Nine considerations chiefly appear in this book. The first is about the creator of the world: if anyone were to follow Iamblichus's and Proclus's method where they interpret that passage from the Timaeus about the world's Demiurge — namely that there the Intellect thinks as many ideas in this living being as the Demiurge of the world considers to arrange species in the world-I think he will interpret it as follows: there are clearly as many as three divine substances between the first principles, that is the Good itself and the world. The first of which, essence is the participant of the Good according to its form, and is the cause above life and intellect. But the second, life is the participant of essence according to its form, and is the formal cause of the intellect. Finally, the third, the intellect is the participant of life according to its form and is the cause of the world. He will name the first Ouranos, the second Kronos, and the third Zeus, and he will think that just as Ouranos is superior to Kronos, and Kronos superior to Zeus, so is essence superior and prior to life, and life superior and prior to intellect. But essence is superior to life to the extent that it diffuses itself wider, and life is superior to mind according to a similar extent. He will thus say that the formal Intellect, Zeus, is the immediate Demiurge or maker of the world (proximum mundifabrum), and that he holds within him the intellective ideas of worldly things: which indeed he would have received from the living intellect, namely from Kronos, in which the ideas are equally intellective and intelligible, which in turn Kronos would have received from the Essential Intellect, namely from Ouranos, in which the ideas are only intelligibles. Such a person, therefore, will interpret the Timaeus as follows, the providence of Zeus conceived to make as many species in the world as the ideas that the Saturnian Intellect turned to contemplate in the living being itself, that is in Ouranos, which as essence is the cause of life. However, for Plotinus there are not three substances so much as there is that one substance which is called the first Intellect, the first Essence, and the first Life. ${ }^{37}$

37 Plotinus, Opera omnia cum latina Marsilii Ficini interpretatione et commentatione, p. 353: Novem praecipue in hoc libro considerationes apparent. Primae est de auctore mundi: ubi siquis viam Iamblichi Proculique sequatur, exponet Timae dictum illud de opifice mundi, scilicet quot ideas intellectus intelligit in ipso vivente, totidem species cogitavit mundi opifex in 
A few points need to be made about Ficino's interpretation Enneads 3.9. First, because he groups Iamblichus's and Proclus's understanding of the Demiurge together it is clear that to interpret this text Ficino employs a passage from Proclus's commentary on the Timaeus, namely a section in book 2 (303.24310.2 ) that discusses various identifications of Plato's Demiurge. ${ }^{38}$ To summarize briefly the relevant material from this section, Proclus (who soon afterwards gives his own and his master Syrianus's opinion about the Demiurge) considers Iamblichus as his intellectual predecessor for his own correct interpretation of the Demiurge. Proclus, like Iamblichus, understands demiurgy according to the law of the mean terms structured according to a theological triad of intelligible, intelligible-intellective, and intellective, each of which, again like Iamblichus, is organized according to the triad being-life-intellect. ${ }^{39}$ Once more like Iamblichus, Proclus identifies Zeus as the Demiurge and the last term of the triad, Intellect, in the third part of the trinity, the intellective, which, to repeat, Ficino expresses as proximus mundifaber.

mundo disponere. Exponet id inquam ita: tres scilicet saltem esse divinas substantias inter principium primum, id est, ipsum bonum atque mundum. Quarum prima secundam formam suam, essentia sit boni particeps, ac insuper vitae intellectusque causa. Secunda vero, secundum formam sit vita, particeps quidem essentiae: intellectus autem formalis causa. Tertia denique per formam sit intellectus, vitae quidem particeps, et causa mundi. Primum nominabit Caelium, secundum vero Saturnum, tertium denique Iovem: tantoque superiorem Saturno Caelium, et Iove Saturnum existimabit, quanto superior priorque essentia est quam vita, et vita quam intellectus. Esse vero essentiam superiorem vita, quatenus amplius se diffundit, et vitam, propter similem amplitudinem esse mentem superiorem. Dicet itaque intellectum formalem, Iovemque esse proximum mundi fabrum, intellectuales ideas mundanarum rerum in se habentem: quas quidem ideas acceperit ab intellectu vitali, scilicet a Saturno, in quo ideae sint intellectuales, et intelligibiles aeque, quas Saturnus habeat ab intellectu essentialis, scilicet ab ipso Caelio, in quo intelligibiles duntaxat sint ideae. Sic igitur Timaeus interpretabitur: Providentia Iovis excogitavit tot in mundo species fabricare, quot animadvertit Saturnium intellectum ideas contemplari, in ipso vivente, id est, in Caelio: qui essentia sit causa vitae. Apud Plotinum vero non tres substantiae, sed una tantum substantia est illa, quae nominatur essentia vitaque prima et intellectus primus.

38 Proclus, In Timaeum, B.303.24-310.2; and book 4 (97.1-102.23), which interprets the exact passage from the Timaeus cited by Plotinus. On how much of the Proclus's In Timaeum Ficino could read see Megna 2003.

39 They are in agreement if one follows Festugière's slight emendation of the text at 308.22 in

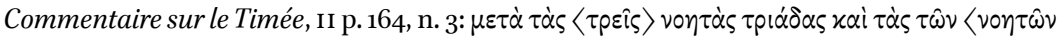

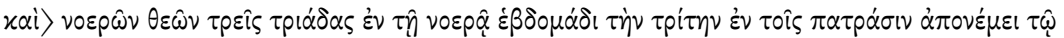
$\delta \eta \mu$ เov $\hat{\omega}$. This agrees with understanding of the text by T. Taylor and a scholion in Proclus,

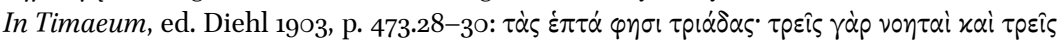

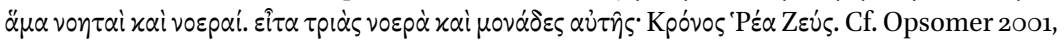

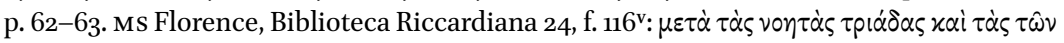

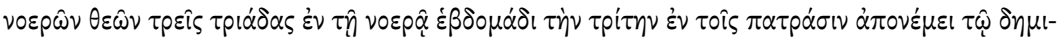

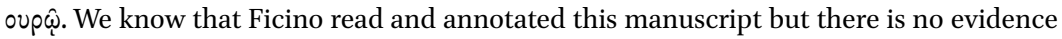


Second, in his interpretation of Enneads 3.9.1 Ficino speaks of the demiurgic triad as consisting of Hesiod's theogony of Ouranos-Kronos-Zeus. Most modern scholars of Proclus explain that Proclus identifies the triad being-lifeintellect not with Ouranos-Kronos-Zeus, but with Kronos-Rhea-Zeus from the Timaeus, as I previously discussed. In both cases, Zeus remains the intellect but being and life are identified with different Gods. As I previously demonstrated, Ficino clearly and accurately reconstructed Proclus's complete system in his manuscript notes to the Platonic Theology, culminating in Zeus's place (after Kronos and Rhea) as the the lowest neighboring intellect, protected by the Kouretes and the liminal boundary. (Figure 2) Why then does Ficino speak of Ouranos-Kronos-Zeus instead of Kronos-Rhea-Zeus in his interpretation of Enneads 3.9.1?

I think Porphyry's organization of the Enneads is significant to Ficino's interpretation. We know that Porphyry broke up Plotinus's lengthy treatise against the Christian Gnostics into four parts that now correspond to Enneads 3.8; 5.8; 5.5; and 2.9. In these tracts Plotinus discusses the nature of demiurgy to argue against the Gnostics, first, that the Intellect and Intelligible world should not be separated into a divided plurality, second, that the intelligible and the sensible world should not be divided into a living thinking being that is intelligible and a dead material being that makes up our world, and, third, that there is theoria or intellectual contemplation at every level of demiurgy, and not simply a preplanned discursive activity from a Christian creator who sets things in motion. Thus, in Enneads 3.8, the treaties that immediately precedes the one on which Ficino is here commenting, Plotinus once more addresses the three principles of being-life-intellect in terms of demiurgy. He explains that all beings (even plants and stones) contemplate. That is, because they are the product of the higher noetic activity of the Intellect, they seek a contemplative return (epistro$p h \hat{e})$ to their originative source. In 1981 Pierre Hadot reconstructed the final section of Enneads 3.8.11 to explain how at the end of Enneads 3.8 Plotinus was actually putting forward his philosophy as an exegesis of Hesiod's theogony: Ouranos, Kronos, and Zeus. Here is Plotinus:

As certainly, one who looks up to the sky and sees the light of the stars thinks of their maker and seeks him, so the man who has contemplated

here that he knew of the scholion to 308.22, although he annotates the manuscript elsewhere, and Megna (Megna 2003) has argued that Ficino's studies of Proclus's In Timaeum were not limited to this manuscript. In any case, Ficino's commentary to Plotinus' Enneads, 3.9.1 indicates that he nonetheless groups Iamblichus's understanding of the Demiurge with Proclus's. 
the intelligible world and observed it closely and wondered at it must seek its maker, too, and enquire who it is who has brought into being something like this, and how, he who produced a son like Intellect, a beautiful boy filled full from himself. ${ }^{40}$

As Hadot explains, even though Plotinus does not mention the three Gods of Hesiod's theogony by name it is clear from the word play that he has Plato's reading of Hesiod in mind. I here quote Hadot: "Like a good Platonic exegete, Plotinus has an obvious starting-point for his criticism in the text of Plato himself, namely the etymology which Plato gives of the name "Kronos" in the Cratylus. Kronos, we are there told, means "Koros-nous", i.e., "intellect" not as "child" (koros, kouros), but as "fulfilment" or "fullness" (Koros)."41 It might be worth adding to Hadot's remarks that this Platonic etymological play is very significant since both senses of xópos share a common etymological root in proto-indo-european *ker- ("to grow") to indicate growth and production, as seen, for example, in creo and creatio in Latin. Thus, in Plotinus's interpretation of Hesiod's theogony, Kronos does not eat his children so much as keep them inside of himself, which Plotinus interprets as meaning not only that the intelligibles are within the Intellect, but that the Intellect can even be identified with its thoughts. Thus, according to Hadot's reconstruction, the genealogy of Gods in Plotinus bears the following theological significance: Ouranos signifies the One; Kronos signifies the Intellect; and Zeus signifies the Soul (see Figure 6).

It is striking that Ficino does a similar reconstruction of Plotinus's application of philosophical principles to a cosmic theogony. He too draws on this closing section of Enneads 3.8.11, which immediately precedes Plotinus's discussion on Plato's Demiurge in Enneads 3.9.1, to interpret Plotinus, Iamblichus, and Proclus's discussion of the Demiurge's genealogy according to Hesiod's theogony of Ouranos-Kronos-Zeus, instead of Kronos-Rhea-Zeus. Thus for Ficino, in this passage the genealogy of Ouranos-Kronos-Zeus in Plotinus does not signify One, Intellect, and Soul (as Hadot reconstructs it), which Ficino finds elsewhere in Enneads 5.1.10 and 5.8.13, but rather being-life-intellect (Figure 7) ${ }^{42}$

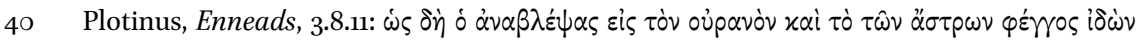

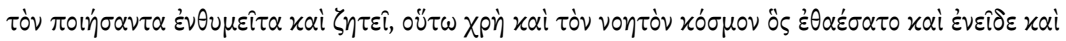

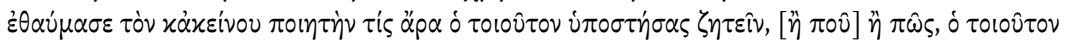

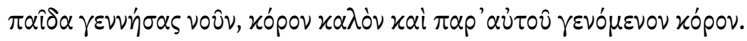

41 Hadot 1981, p. 127.

42 Ms Paris, Bibliothèque nationale de France, Gr. 1816, f. 213: Coelus-ipsum bonum; Saturnus -intellectus divinus; Iuppiter - anima mundi; exposit hic fabulas horum trium. 


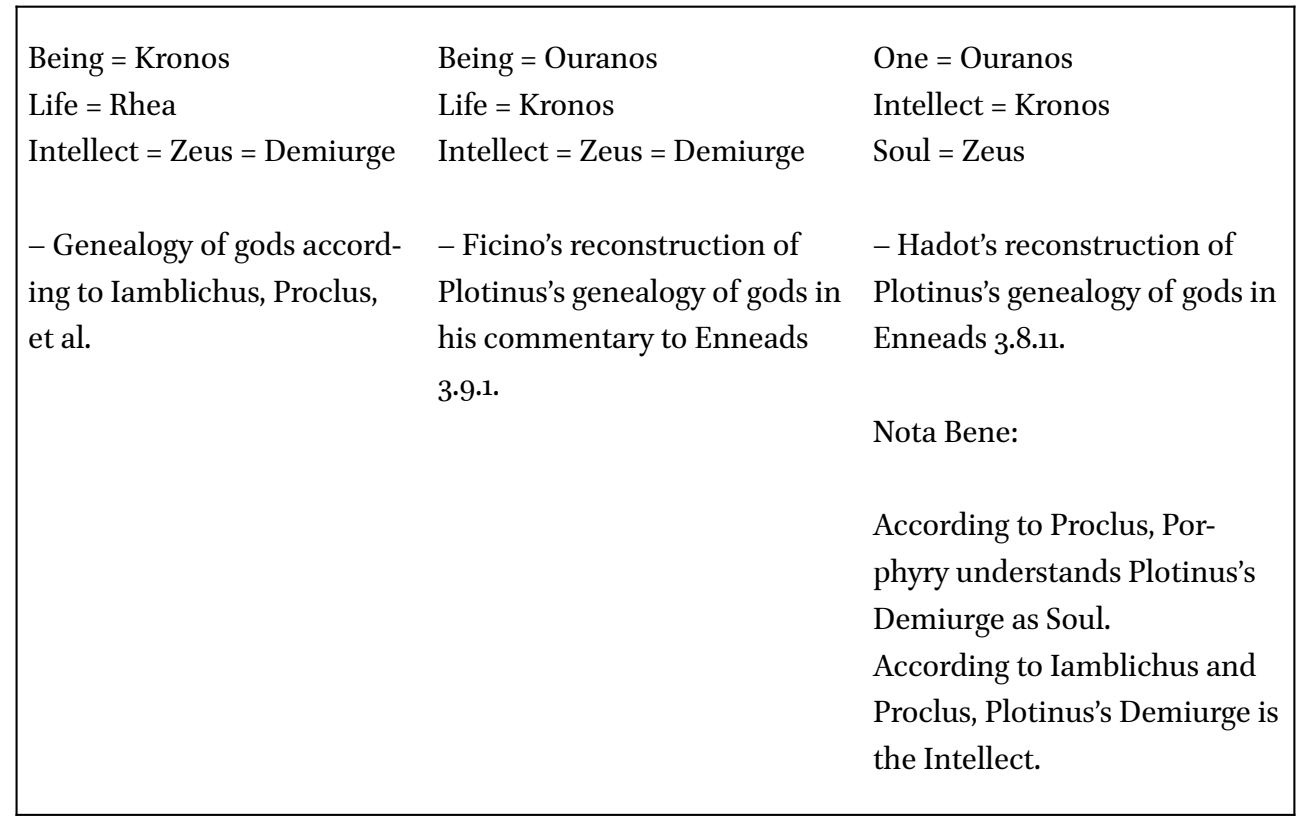

FIGURE 6 Comparative table of theogonies relevant to Ficino's reconstruction of Neoplatonic theologies

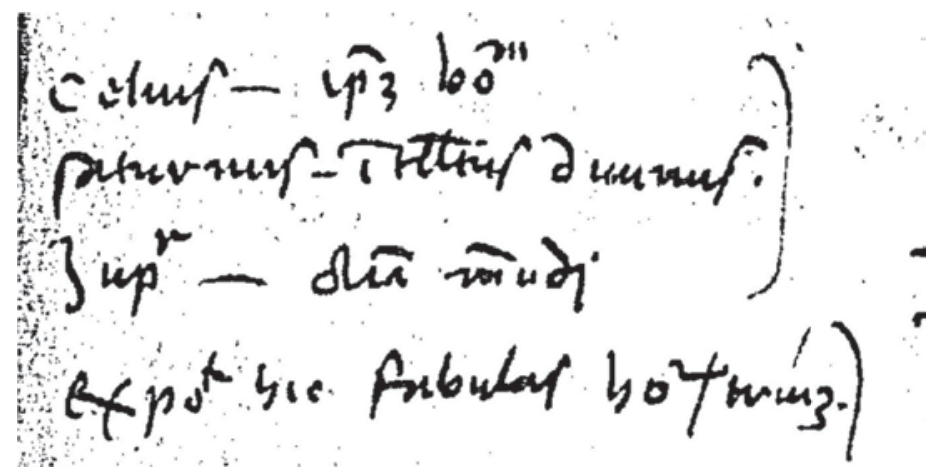

FIGURE 7 MS. Paris, Bibliothèque nationale de France, Gr. 1816, f. $213^{\mathrm{v}}$

It is precisely with this identification that he critiques Iamblichus's and Proclus's sequence of the triad. It would thus seem that Plotinus even inverts their order of the triad with intellect, instead of being, standing at the forefront of the series. This is the exact reason why Ficino writes in the margins of Enneads 3.8 in his manuscript: "See Proclus's established distinction that places being above life and life above intellect, and this will be refuted." (Figure 8). 


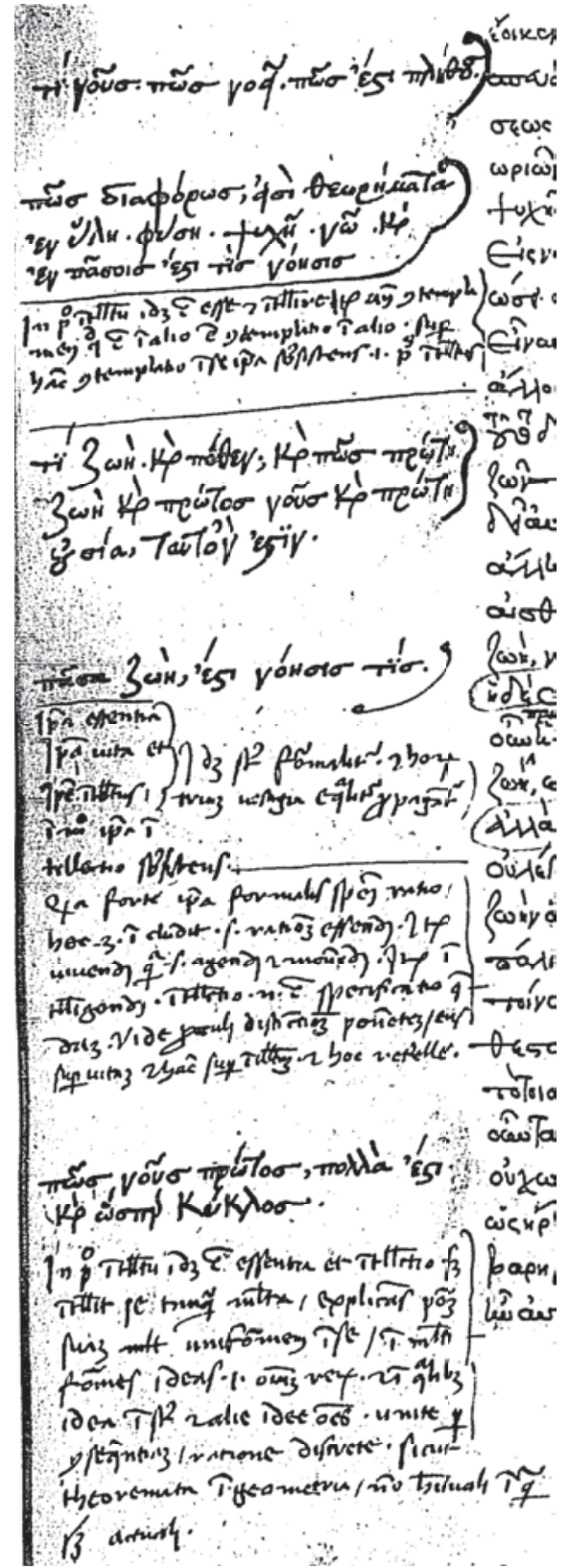

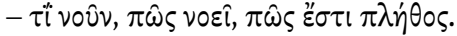

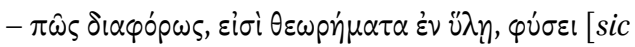

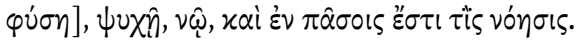

- In primo intellectu idem est esse et intelligere. Item ante contemplamen, quod est in alio, est contemplatio in alio, super hanc, contemplatio in se ipsa subsistens, id est primus intellectus.

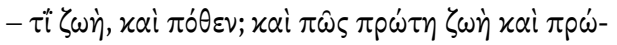

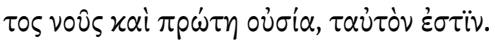

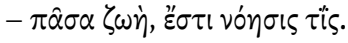

ipsa essentia

ipsa vita et

ipse intellectus

immo ipsa intellectio subsistens.

idem sunt formaliter et horum trium vestigia aequaliter propagantur.

Quia forte ipsa formalis speciei ratio haec 3 includit, scilicet rationem essendi, item vivendi, quia scilicet agendi et movendi, item intelligendi. Intellectio enim est specificatio quaedam. Vide Proculi distinctionem ponentem ens super vitam et hanc super intellectum et hoc refelletur.

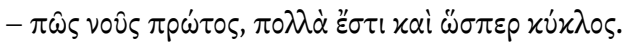
- In primo intellectu idem est essentia et intellectio, sed intelligit se tanquam multa, explicans potentiam suam uniformem in se, in multiformes ideas, id est omnium rerum. Et in qualibet idea insunt et aliae ideae omnes unitae per consequentiam ratione discretae, sicut theoremata in geometria, non habituali inquam sed actuali.

FIGURE 8 MS. Paris, Bibliothèque nationale de France, Gr. 1816, f. $127^{\mathrm{v}}$ 
As is clear from Ficino's extensive marginalia and printed comments on Enneads 3.8 and 3.9, Ficino contrasts the ontological priority that he finds in Proclus with the noetic one in Plotinus, and Ficino is aware that they seem to be contradictory insofar as Enneads 3.8 makes intellect precede the other two terms.

This final point is of the utmost importance to Ficino for two reasons. First, Ficino finds a closer affiliation with the Plotinian/Porphyrian understanding than a strict Iamblichean understanding of demiurgy (though Ficino is often still very much seduced by many elements of Iamblichean and Proclean mediation in metaphysical hierarchies). Second, it allows him to invoke Plotinus's aid to defend Pseudo-Dionysius's collapsing of being-life-intellect as divine names for a single God. This demonstrates how Ficino's thinking on PseudoDionysius's relationship to the Platonists had advanced from Thomas Aquinas's position. For, although Ficino adopts a similar strategy as the Liber de causis and the Corpus Dionysiacum of collapsing the Proclean triad, Ficino is also acutely aware that Pseudo-Dionysius's divine hierarchy is also so very close to Iamblichus and Proclus:

In distinguishing the orders of angels, Dionysius made particular use of the numbers three and nine, and occasionally of seven. We find the number twelve in the Christian mysteries. Iamblichus and Proclus, the Platonists, follow Dionysius here. For they divide the highest and middle angels into three and nine orders; but the angels who follow are divided into seven orders, and the lowest angels into twelve. ${ }^{43}$

Because Ficino inverts the real chronology of historical dependence of PseudoDionysius on Iamblichus and Proclus, the resemblances between their respective derived orders of divine hierarchies creates tensions for him. On the one hand, while Ficino clearly understands that the Corpus Dionysiacum repeatedly employs Iamblichean-Proclean triadic mean terms, on the other hand, he is aware that unlike Iamblichus and Proclus, the author of the Corpus wishes to identify the terms being, life, intellect, as different names of a single God, and not different Gods emanating from a single source, the One. Ficino, therefore,

43 Marsilio Ficino, Platonic Theology, 1.5.14: In distinguendis autem angelorum Dionysius ternario novenarioque numero in primis, necnon interdum septenario utitur. Quinetiam duodenarium in Christianorum mysteriis reperimus. Idem et Iamblichus Proclusque Platonici post Dionysium observarunt. Supremos enim et medios angelos ternario et novenario dividunt, sequentes autem septenario, postremos denique duodenario ordinum numero partiuntur. 
found solace in Plotinus's solution of differentiating the terms noetically but not separating them ontologically. Aquinas's preoccupation with Platonism in his own commentaries on Pseudo-Dionysius and the Liber de causis emerges from his interpretation of De divinis nominibus 5 .

A few concluding remarks on Ficino's commentary on this section of the Corpus Dionysiacum are necessary to compare his treatment to Aquinas:

But some Platonists, whom Proclus follows, not only place essence in itself, life in itself, intellect in itself in the first intellect as though they were formal rationes of the things that follow, but they also separate them from it as though they were certain divine substances distinct among themselves, principles of their own orders, so that essence itself is simply the principle of beings, by which ratio they are things that exist, life itself the leader of the living, by which ratio they are things that live, and the intellect itself, of the things that think. The Plotinian and Porphyrian opinion, even if haphazardly, agrees much more with Dionysius than does the opinion of Proclus. ${ }^{44}$

First, Ficino goes on to argue, following the line of reasoning expressed in proposition 1 of the Liber de causis or more specifically to Proclus's own propositions 7 and 56 from the Elements of Theology, that the priority of being as a separate substance in the triad would contradict the principle that "the superior cause emits the more powerful effect." Second, Plotinus's identification of the triad being-life-intellect with Intellect presents Ficino with the alternative that one does not need to hyposthasize each term as distinct substances and Gods like Proclus. Third, Ficino also follows Plotinus's argument in Enneads 3.9 that the different ideas of being-life-intellect, and therefore the Demiurge too, can be distinguished not ontologically as separate substances but only conceptually by reason. In short, in Plotinus, Ficino finds a supportive voice for collapsing the triad being-life-intellect, but not, however, for collapsing the first two hypotheses of the Parmenides.

44 Marsilio Ficino, De divinis nominibus interprete, p. 164: Nonnulli vero Platonicorum, quos Proculus est secutus, ipsam per se essentiam, ipsam per se vitam, ipsam intelligentiam, non solum in primo collocant intellectu tanquam formales sequentium rationes, sed etiam inde segregant tanquam substantias quasdam divinas inter se distinctas ordinum suorum principia, ut ipsam essentiam principium entium simpliciter qua ratione sunt entia, vitam ipsam viventum ducem qua ratione viventia, intellectum ipsum intelligentium. Plotinica Porphyrianaque opinio, etsi non undequaque, multo tamen magis quam Proculi Dionysio consonat. See also my discussion in Robichaud 2016, esp. p. 81-86. 
What Ficino understood after he read newly discovered works by Proclus was a much more complex understanding of ancient Platonism than anyone since Antiquity. Two brief but related examples illustrate this. First, in his commentary on the De divinis nominibus, Aquinas stopped short of a full analysis of Dionysius's Platonism as he did for the Liber de causis, stating reservedly that "Dionysius often writes in the style and in the way of speaking of the Platonists, which is out of fashion among moderns." 45 Ficino was in a different position than Aquinas. Not only did he master Greek at a very young age, he had access to, and to be more precise actively worked at expanding, a much richer corpus of writings from Plato and Neoplatonists than was available in Aquinas's day. Studying these texts compelled him to argue that in order to understand the Corpus Dionysiacum correctly one needs to recognize that this Christian author is a Platonist working in a Platonic tradition. He declares this fact in his prefaces and commentaries to the De divinis nominibus and the De mystica theologia. Despite the fact that Ficino still argues for Dionysius's apostolic authority and that he supports Pseudo-Dionysius's collapsing of the Proclean triad of Gods into divine names of a single God, Ficino was still criticized by his contemporaries, most notably by Jacques Lefèvre d'Étaples in his Theologia vivificans, for insisting that the Corpus Dionysiacum is dependent on the Platonic tradition. Lefèvre, however, did not have the same degree of Platonic and philosophical erudition, and would not have comprehended how Ficino was able to explain that the triad being-life-intellect employed by the author of the Corpus Dionysiacum had its source in Plato's Sophist, as E.R. Dodds would demonstrate with great precision centuries later. ${ }^{46}$

\section{Bibliography}

\section{Manuscripts}

Florence, Biblioteca Riccardiana, 24.

Biblioteca Riccardiana, 70.

Paris, Bibliothèque nationale de France, Gr. 1816.

45 Thomas Aquinas, Super De divinibus nominibus, prooemium: plurumque utitur stilo et modo loquendi quo utebantur Platonici, qui apud modernos est inconsuetus.

46 For Lefèvre's criticism of Ficino see Toussaint 1999, p. 404-413. For Ficino's comments on the triad in the Sophist see Ficino 1989, p. 245-249. 


\section{Primary Sources}

Aristotle, Metaphysics, ed. W.D. Ross, Oxford, Clarendon Press, 1924.

Aristotle, Metaphysics, trans. H. Tredennick, Cambridge, MA, Harvard University Press, 1933.

Liber de causis, ed. A. Pattin, "Le Liber de causis. Édition établie à l' aide de go manuscrits avec introduction et notes", in Tijdschrift voor Filosofie 28, 1966, p. 90-203.

Marsilio Ficino, Commentary on the Phaedrus in Marsilio Ficino and the Phaedran Charioteer, ed. and trans. M.J.B. Allen, Berkeley, University of California Press, 1981.

Marsilio Ficino, Commentary on the Sophist in Icastes: Marsilio Ficino's Interpretation of Plato's Sophist, ed. and trans. M.J.B. Allen, Berkeley, University of California Press, 1989.

Marsilio Ficino, Platonic Theology, ed. and trans. M.J.B. Allen, with J. Hankins and W. Bowen, 6 volumes, Cambridge (MA), Harvard University Press, 200o-2006.

Marsilio Ficino, Dionysii Areopagitae, De mystica theologia, De divinis nominibus, interprete Marsilio Ficino, ed. P. Podolak, Naples, M. D’Auria Editore, 2011.

Marsilio Ficino, Commentary on Plato's Parmenides, ed. and trans. M. Vanhaelen, Cambridge (MA) Harvard University Press, 2012.

Marsilio Ficino, Commento al Parmenide di Platone, ed. and trans. F. Lazzarin, Florence, Olschki, 2012.

Plato, Platonis opera, ed. J. Burnet, Oxford, Oxford University Press, 1903.

Plato, Sophist, trans. H.N. Fowler, Cambridge (MA), Harvard University Press, 1921.

Plato, Timaeus, trans. W.R.M. Lamb, Cambridge (MA), Harvard University Press, 1925.

Plotinus, Opera omnia cum latina Marsilii Ficini interpretatione et commentatione, Basel, 1580, facsimile, ed. S. Toussaint, Paris, Les éditions du Miraval, 2008.

Plotinus, Enneads, trans. A.H. Armstrong, Cambridge (MA), Harvard University Press, 1966-1988.

Proclus, In Platonis Timaeum Commentaria, ed. E. Diehl, Leipzig, Teubner, 1903.

Proclus, The Elements of Theology, ed. E.R. Dodds, Oxford, Oxford University Press, 1963.

Proclus, Commentaire sur le Timée, 5 volumes, trans. A.J. Festugière, Paris, Vrin, 19661968.

Proclus, Théologie Platonicienne, ed. H.D. Saffrey, L.G. Westerink, 6 volumes, Paris, Les Belles Lettres, 2003.

Proclus, Commentary on Plato's Timaeus, trans. H. Tarrant, Cambridge, Cambridge University Press, 2007-2017.

Dionysius the Ps.-Areopagite, Corpus Dionysiacum, trans. C. Luibheid, New York, Paulist Press, 1987.

Dionysius the Ps.-Areopagite, Corpus Dionysiacum I, ed. B.R. Suchla, Berlin, Walter De Gruyter, 1990.

Thomas Aquinas, Super Librum de causis expositio, ed. H.-D. Saffrey, Fribourg, Société Philosophique, 1954. 
Thomas Aquinas, De substantiis separatis, in Opera omnia, ed. Leon. 40, Roma, Editori di San Tommaso, 1968.

\section{Secondary Sources}

Allen, M.J.B. (1986), "The Second Ficino-Pico Controversy: Parmenidean Poetry, Eristic, and the One", in G.C. Garfagnini (ed.), Marsilio Ficino e il ritorno di Platone: Studi e documenti, vol. 2, Florence, Olschki p. 419-455.

Allen, M.J.B. (1987), "Marsilio Ficino's Interpretation of Plato's Timaeus and Its Myth of the Demiurge", in J. Hankins, J. Monfasani, F. Purnell Jr. (eds), Supplementum Festivum, Studies in Honor of Paul Oskar Kristeller, Binghamton, Medieval and Renaissance Texts and Studies, p. 399-439.

Allen, M.J.B. (2014), “Marsilio Ficino”, in S. Gersh (ed.), Interpreting Proclus: From Antiquity to the Renaissance, Cambridge, Cambridge University Press, p. 353-379.

Beierwaltes, W. (1979), Proklos: Grundzüge seiner Metaphysik, Frankfurt a. M., Klostermann.

Beierwaltes, W. (2002), "Marsilio Ficinos Deutung des Platonischen Parmenides", in Würzburger Jahrbücher für die Altertumswissenschaft 26, p. 201-209.

Brisson, L. (1987), "Proclus et l' Orphisme”, in J. Pépin, H.D. Saffrey (eds), Proclus lecteur et interprète des Anciens. Actes du colloque international du cNRs (2-4 octobre 1985), Paris, Éditions du CNRS, p. 43-104.

Brisson, L. (2017), "Proclus' Theology", in P. d'Hoine, M. Martijn (eds), All from One: A Guide to Proclus, Oxford, Oxford University Press, p. 205-222.

Calma, D. (2016) (ed.), Neoplatonism in the Middle Ages, 2 volumes, Turnhout, Brepols.

Calma, D. (2019) (ed.), Reading Proclus and the Book of Causes. Volume I: Western Scholarly Networks and Debates, Leiden, Brill.

Copenhaver, B. (1988), "Hermes Trismegistus, Proclus and the Question of a Theory of Magic in the Renaissance", in I. Merkel, A.G. Debus (eds), Hermeticism and the Renaissance: Intellectual History and the Occult in Early Modern Europe, Washington, Folger Shakespeare Library, p. 79-110.

D’Ancona, C. (1995), Recherches sur le Liber de causis, Vrin, Paris.

D’Ancona, C. (2014), “The Liber de causis”, in S. Gersh (ed.), Interpreting Proclus: From Antiquity to the Renaissance, Cambridge, Cambridge University Press, p. 137-162.

Deuse, W. (1977), "Der Demiurg Bei Porphyrios Und Jamblich”, in C. Zintzen (ed.), Die Philosophie des Neuplatonismus, Darmstadt, Wissenschaftliche Buchgesellschaft.

d'Hoine, P. (2008), "The Intelligent Design of the Demiurge: On an Argument from Design in Proclus", in Études platoniciennes 5, p. 63-9o.

d'Hoine, P. (2017), "Platonic Forms and the Triad of Being, Life, and Intellect", in P. d'Hoine, M. Martijn (eds), All from One: A Guide to Proclus, Oxford, Oxford University Press, p. 98-121.

Dillon, J. (1969), "Plotinus, Enn. 3.9.1, and LaterViews on the Intelligible World", in Transactions and Proceedings of the American Philological Association 100, p. 63-70. 
Dillon, J. (2000), "The Role of the Demiurge in the Platonic Theology", in Proclus et la Théologie Platonicienne, Actes du Colloque International de Louvain (13-16 mai 1998). En l'honneur de H.D. Saffrey et L.G. Westerink, Leuven, University Press / Paris, Les Belles Lettres, p. 339-349.

Étienne, A. (1997), "Marsile Ficin, lecteur, interprète du Parménide à la Renaissance", in A. Neschke-Hentschke, A. Étienne (eds), Images de Platon et lectures de ses oeuvres. Les interprétations de Platon à travers les siècles, Louvain-la-Neuve, Éditions de l'Institut supérieur de philosophie, p. 153-185.

Förstel, C. (2006), "Marsilio Ficino e il Parigino Greco 1816 di Plotino", in S. Gentile, S. Toussaint (eds), Marsilio Ficino. Fonti, testi, fortuna, Rome, Edizioni di Storia e Letteratura, p. $65^{-88 .}$

Gentile, S. (1990), "Sulle prime traduzioni del greco di Marsilio Ficino", in Rinascimento 3०, p. 57-104.

Gentile, S., Niccoli, S., Viti, P. (eds) (1984), Marsilio Ficino e il ritorno di Platone. Mostra di manoscritti, stampe e documenti (17 maggio-16 giugno 1984), Florence, Le Lettere.

Gersh, S. (1978), From Iamblichus to Eriugena: An Investigation of the Prehistory and Evolution of the Pseudo-Dionysian Tradition, Leiden, Brill.

Gersh, S. (2014) (ed.), Interpreting Proclus: From Antiquity to the Renaissance, Cambridge, Cambridge University Press.

Hadot, P. (1981), "Ouranos, Kronos and Zeus in Plotinus' Treatise Against the Gnostics", in A.H. Armstrong, H.J. Blumenthal, R.A. Markus (eds), Neoplatonism and Early Christian Thought: Essays in Honour of A.H. Armstrong, London, Ashgate.

Hankey, W.J. (1997), "Dionysian Hierarchy in Thomas Aquinas: Tradition and Transformation", in Ysabel de Andia (ed.), Deny l'Aréopagite et sa postérité en Orient et en Occident. Actes du colloque international (Paris 21-24 septembre 1994), Paris, Institut d'études augustiniennes, p. 405-438.

Hankey, W.J. (2002), "Aquinas and the Platonists", in S. Gersh, M.J.F.M. Hoenen (eds), The Platonic Tradition in the Middle Ages: A Doxographic Approach, Berlin, De Gruyter, p. 279-324.

Henle, R.J. (1956), Saint Thomas and Platonism. A Study of the Plato and Platonici Texts in the Writings of Saint Thomas, The Hague, Martinus Nijhoff, 1956.

Henry, P. (1948), Études plotiniennes II: Les manuscrits des Ennéades, Paris, Desclée de Brouwer.

Klibansky, R. (1943), "Plato's Parmenides in the Middle Ages and the Renaissance", in Medieval and Renaissance Studies 1, p. 281-330.

Klutstein, I. (1987), Marsilio Ficino et la théologie ancienne. Oracles chaldä̈ques, hymnes orphiques, hymnes de Proclus, Florence, Olschki.

Kristeller, P.O. (1987), "Proclus as a Reader of Plato and Plotinus, and His Influence in the Middle Ages and the Renaissance", in J. Pépin, H.D. Saffrey (eds), Proclus lecteur et interprète des Anciens. Actes du colloque international du cNRs (2-4 octobre 1985), 
Paris, Éditions du CNRS, p. 191-211. Repr. in Id., Studies in Renaissance Thought and Letters, Rome, Edizioni di storia e letteratura, vol. 4, p. $115^{-137}$.

Kutash, E. (2011), The Ten Gifts of the Demiurge:Proclus' Commentary on Plato's Timaeus, London, Bloomsbury.

Lazzarin, F. (2003), "Notes sull' interpretazione ficiniana del Parmenide di Platone", in Accademia 5, p. 17-37.

Malmsheimer, A. (2001), Platons Parmenides und Marsilio Ficinos Parmenides-Kommentar: Ein kritischer Vergliech, Amsterdam, B.R. Grüner.

Megna, P. (2003), "Marsilio Ficino e il commento al Timeo di Proclo", in Studi medievali e umanistici 1, p. 93-135.

Megna, P. (2004), "Per Ficino e Proclo", in F. Bausi, V. Fera (eds), Laurentia laurus: Scritti offerti a Mario Martelli, Messina, Centro Interdipartimentale di Studi Umanistici, p. $313-362$.

Monet, D. (2000), “Le démiurge du Timée aux Ennéades: question des causes et théorie des principes", in Kairos 16, p. 209-226.

Opsomer, J. (2000), "Proclus on Demiurgy and Procession: A Neoplatonic Reading of the Timaeus", in M.R. Wright (ed.), Reason and Necessity: Essays on Plato's Timaeus, London, Duckworth, p. 113-143.

Opsomer, J. (2001), "Who in Heaven is the Demiurge? Ploclus' Exegesis of Plato Tim. 28C 3-5", in Ancient World 32, p. 52-70.

Opsomer, J. (2003), “La Démiurgie des jeunes dieux selon Proclus", in Les études classiques 71, p. 5-49.

Opsomer, J. (2005), "A Craftsman and His Handmaiden. Demiurgy According to Plotinus", in T. Leinkauf, C. Steel (eds), Platons Timaios als Grundtext der Kosmologie in Spätantike, Mittelalter und Renaissance / Plato's Timaeus and the Foundations of Cosmology in Late Antiquity, the Middle Ages and Renaissance, Leuven, Leuven University Press, p. 67-102.

Opsomer, J. (2017), “The Natural World”, in P. d'Hoine, M. Martijn (eds), All from One: A Guide to Proclus, Oxford, Oxford University Press, p. 139-166.

O'Rourke, F. (2005), Pseudo-Dionysius and the Metaphysics of Aquinas, Notre Dame, University of Notre Dame Press.

Rabassini, A. (1999), "Il Bene e le ombre: Excerpta ficiniana del Commento alla Repubblica di Proclo", in Accademia 1, p. 49-65.

Robichaud, D.J.-J. (2016), “Fragments of Marsilio Ficino's Translation and Use of Proclus' Elements of Theology and Elements of Physics: Evidence and Study", in Vivarium:Journal for Medieval and Early-Modern Philosophy and Intellectual Life 54.1, p. 46-107.

Robichaud, D.J.-J. (2017a), "Ficino on Force, Magic, and Prayer: Neoplatonic and Hermetic Influences in Ficino's Three Books on Life", in Renaissance Quarterly 70.1, p. 4487 .

Robichaud, D.J.-J. (2017b), “Working with Plotinus: A Study of Marsilio Ficino's Textual 
and Divinatory Philology", in F. Ciccolella, L. Silvano (eds), Teachers, Students, and Scholars of Greek in the Renaissance, Leiden, Brill, p. 120-154.

Robichaud, D.J.-J. (2018), Plato's Persona: Marsilio Ficino, Renaissance Humanism, and Platonic Traditions, Philadelphia, Pennsylvania University Press.

Robichaud, D.J.-J. (2020), "Ficino and the Nodus Divinus: Timaean and Iamblichean Mean Terms and the Soul in Platonic Theology 1-4", in Bruniana \& Campanelliana 26.2, p. 379-401.

Robichaud, D.J.-J. (2021a), "Valla and Erasmus on the Dionysian Question", in M. Edwards, D. Pallis, G. Steiris (eds), The Oxford Handbook of Dionysius the Areopagite, Oxford: Oxford University press, p. 491-515.

Robichaud, D.J.-J. (2021b), "Cardinal Bessarion and the Corpus Dionysiacum: Platonic Love Between East and West”, in S. Klitenic Wear, F. Lauritzen (eds), Byzantine Platonists (284-1453), Washington, The Catholic University of America Press, 2021, p. 231-253.

Robichaud, D.J.-J., Soranzo, M. (2017), "Philosophical or Religious Conversion? Marsilio Ficino, Plotinus's Enneads and Neoplatonic Epistrophê", in S. Marchesini (ed.), Simple Twists of Faith: Changing Beliefs, Changing Faiths: People and Places, Verona, Alteritas, p. ${ }^{135^{-166 .}}$

Saffrey, H.-D. (1959), "Notes platoniciennes de Marsile Ficin dans un manuscrit de Proclus", in Bibliothèque d'Humanisme et Renaissance 21, p. 161-184, Rep. in H.-D. Saffrey, L'Héritage des anciens au Moyen Âge et à la Renaissance, Paris, Vrin, 2002, p. 69-94. Sanzotta, V. (2014), "Some Unpublished Notes by Marsilio Ficino on Plato's Parmenides in Ms Laur. 89 sup. 71", in Journal of the Warburg and Courtauld Institute 77, p. 211-219. Steel, C. (2013), "Ficino and Proclus: Arguments for the Platonic Doctrine of the Ideas", in J. Hankins, F. Meroi (eds), The Rebirth of Platonic Theology, Florence, Olschki.

Steel, C. (2014), 'William of Moerbeke, Translator of Proclus', in S. Gersh (ed.), Interpreting Proclus: From Antiquity to the Renaissance, Cambridge, Cambridge University Press, p. 247-263.

Taylor, R.C. (1986), "The Kalām fì maḥ al-khair (Liber de causis) in the Islamic Philosophical Milieu", in J. Kraye, W.F. Ryan, C.B. Schmitt (eds), Pseudo-Aristotle in the Middle Ages: The "Theology" and Other Texts, London, Warburg Institute, p. 37-52.

Taylor, R.C. (1989), "Remarks on the Latin Text and the Translator of the The Kaläm $f$ mahd al-khair / Liber de causis", in Bulletin de philosophie médiévale 31, p. 75-102.

Toussaint, S. (1999), "L' Influence de Ficin à Paris et le Pseudo-Denys des humanistes: Traversari, Cusain, Lefèvre d'Étaples. Suivi d'un passage inédit de Marsile Ficin”, in Bruniana \& Campanelliana, Ricerche filosofiche e materiali storico-testuali 5.2, p. 381414.

Van Riel, G. (2008), Damascius: Commentaire sue le Philèbe de Platon, Paris, Les Belles Lettres. 